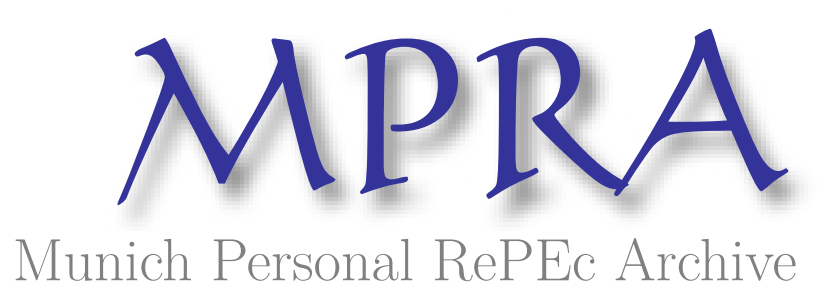

\title{
Practical concepts in Contract Law
}

Ehsan, zarrokh

14 August 2008

Online at https://mpra.ub.uni-muenchen.de/10077/

MPRA Paper No. 10077, posted 01 Jan 2009 09:21 UTC 


\section{Practical concepts in Contract Law}

Author: EHSAN ZARROKH

LL.M at university of Tehran

E-mail: e.zarrokh@gmail.com

TEL: 00989183395983

URL: http://www.zarrokh2007.20m.com

\section{Abstract}

A contract is a legally binding exchange of promises or agreement between parties that the law will enforce. Contract law is based on the Latin phrase pacta sunt servanda (literally, promises must be kept) [1]. Breach of a contract is recognised by the law and remedies can be provided. Almost everyone makes contracts everyday. Sometimes written contracts are required, e.g., when buying a house [2]. However the vast majority of contracts can be and are made orally, like buying a law text book, or a coffee at a shop. Contract law can be classified, as is habitual in civil law systems, as part of a general law of obligations (along with tort, unjust enrichment or restitution).

Contractual formation

Keywords: contract, important concepts, legal analyse, comparative.

The Carbolic Smoke Ball offer, which bankrupted the Co. because it could not fulfill the terms it advertised

In common law jurisdictions there are three key elements to the creation of a contract. These are offer and acceptance, consideration and an intention to create legal relations. In civil law systems the concept of consideration is not central. In addition, for some contracts formalities must be complied with under what is sometimes called a statute of frauds.

One of the most famous cases on forming a contract is Carlill v. Carbolic Smoke Ball Company, decided in nineteenth century England. A medical firm advertised that its new wonder drug, the smokeball, would cure people's flu, and if it did not, buyers would get $£ 100$. Lots of people sued for their $£ 100$ when it did not work. Fearing bankruptcy, Carbolic argued the advert was not to be taken as a serious, legally binding offer. It was merely an invitation to treat, or mere 
puff, a gimmick. But the court of appeal held that to a reasonable man Carbolic had made a serious offer. People had given good "consideration" for it by going to the "distinct inconvenience" of using a faulty product. "Read the advertisement how you will, and twist it about as you will," said Lord Justice Lindley, "here is a distinct promise expressed in language which is perfectly unmistakable".

Offer and acceptance

Perhaps the most important feature of a contract is that one party makes an offer for a bargain that another accepts. This can be called a 'concurrence of wills' or a 'meeting of the minds' of two or more parties. There must be evidence that the parties had each from an objective perspective engaged in conduct manifesting their assent, and a contract will be formed when the parties have met such a requirement. An objective perspective means that it is only necessary that somebody gives the impression of offering or accepting contractual terms in the eyes of a reasonable person, not that they actually did want to contract.

The case of Carlill v. Carbolic Smoke Ball Co. (above) is an example of a 'unilateral contract', where an offer is made to the whole world and acceptance comes from particular people upon their fulfillment of the contractual terms or the condition precedent. In the U.S., the general rule is that in "case of doubt, an offer is interpreted as inviting the offeree to accept either by promising to perform what the offer requests or by rendering the performance, as the offeree chooses."

Offer and acceptance does not always need to be expressed orally or in writing. An implied contract is one in which some of the terms are not expressed in words. This can take two forms. A contract which is implied in fact is one in which the circumstances imply that parties have reached an agreement even though they have not done so expressly. For example, by going to a doctor for a checkup, a patient agrees that he will pay a fair price for the service. If he refuses to pay after being examined, he has breached a contract implied in fact. A contract which is implied in law is also called a quasi-contract, because it is not in fact a contract; rather, it is a means for the courts to remedy situations in which one party would be unjustly enriched were he or she not required to compensate the other. For example, say a plumber who accidentally installs a sprinkler system in the lawn of the wrong house. The owner of the house had 
learned the previous day that his neighbor was getting new sprinklers. That morning, he sees the plumber installing them in his own lawn. Pleased at the mistake, he says nothing, and then refuses to pay when the plumber hands him the bill. Will the man be held liable for payment? Yes, if it could be proven that the man knew that the sprinklers were being installed mistakenly, the court would make him pay because of a quasi-contract. If that knowledge could not be proven, he would not be liable.

Consideration and estoppel

Consideration is a controversial requirement for contracts under common law. It is not necessary in civil law systems, and for that reason has come under increasing criticism. The idea is that both parties to a contract must bring something to the bargain. This can be either conferring an advantage on the other party, or incurring some kind of detriment or inconvenience. Three rules govern consideration.

- Consideration must be sufficient, but need not be adequate. For instance, agreeing to buy a car for a penny may constitute a binding contract. While consideration need not be adequate, contracts in which the consideration of one party greatly exceeds that of another may nevertheless be held invalid for lack of sufficient consideration. In such cases, the fact that the consideration is exceedingly unequal can be evidence that there was no consideration at all. Such contracts may also be held invalid for other reasons such as fraud, duress, unequal bargaining power, or contrary to public policy. In some situations, a collateral contract may exist, whereby the existence of one contract provides consideration for another. Critics say consideration can be so small as to make the requirement of any consideration meaningless.

- Consideration must not be from the past. For instance, in Eastwood v. Kenyon, the guardian of a young girl raised a loan to educate the girl and to improve her marriage prospects. After her marriage, her husband promised to pay off the loan. It was held that the guardian could not enforce the promise as taking out the loan to raise and educate the girl was past consideration, because it was completed before the husband promised to repay it.

- Consideration must move from the promisee. For instance, it is good consideration for person $A$ to pay person $C$ in return for services rendered by 
person B. If there are joint promisees, then consideration need only to move from one of the promisees.

Civil law systems take the approach that an exchange of promises, or a concurrence of wills alone, rather than an exchange in valuable rights is the correct basis. So if you promised to give me a book, and I accepted your offer without giving anything in return, I would have a legal right to the book and you could not change your mind about giving me it as a gift. However, in common law systems the concept of culpa in contrahendo, a form of 'estoppel', is increasingly used to create obligations during pre-contractual negotiations. Estoppel is an equitable doctrine that provides for the creation of legal obligations if a party has given another an assurance and the other has relied on the assurance to his detriment. A number of commentators have suggested that consideration be abandoned, and estoppel be used to replace it as a basis for contracts. However, legislation, rather than judicial development, has been touted as the only way to remove this entrenched common law doctrine. Lord Justice Denning famously stated "The doctrine of consideration is too firmly fixed to be overthrown by a side-wind."

Intention to be legally bound

There is a presumption for commercial agreements that parties intend to be legally bound. On the other hand, many kinds of domestic and social agreements are unenforceable on the basis of public policy, for instance between children and parents. One early example is found in Balfour v. Balfour. Using contractlike terms, Mr Balfour had agreed to give his wife $£ 30$ a month as maintenance while he was living in Ceylon (Sri Lanka). Once he left, they separated and Mr Balfour stopped payments. Mrs Balfour brought an action to enforce the payments. At the Court of Appeal, the Court held that there was no enforceable agreement as there was not enough evidence to suggest that they were intending to be legally bound by the promise.

The case is often cited in conjunction with Merritt v. Merritt. Here the court distinguished the case from Balfour v. Balfour because Mr and Mrs Merritt, although married again, were estranged at the time the agreement was made. Therefore any agreement between them was made with the intention to create legal relations.

The abstraction principle 
Germany has a special approach to contracts, which ties into property law. Their 'abstraction principle' (Abstraktion sprinzip) means that the personal obligation of contract forms separately to the title of property being conferred. When contracts are invalidated for some reason, e.g. a car buyer was so drunk that he lacked legal capacity to contract; the contractual obligation to pay can be invalidated separate from proprietary title of the car. Unjust enrichment law, rather than the law of contract, is then used to restore title to the rightful owner. Formalities and writing

Contrary to common wisdom, an informal exchange of promises can still be binding and legally as valid as a written contract. A spoken contract should be called an "oral contract", but it is often erroneously called a "verbal contract." Any contract that uses words, spoken or written, is a verbal contract. Thus, all oral contracts and written contracts are verbal contracts. This is in contrast to a "non-verbal, non-oral contract," also known as "a contract implied by the acts of the parties", which can be either implied in fact or implied in law.

Most jurisdictions have formal requirements for certain kinds of contracts to be valid. Formalities are especially required for contracts involving large amounts of money, like real estate. For example, in the U.S. a contract is unenforceable if it violates the statute of frauds. An example of the above is an oral contract for the sale of a motorcycle for US\$5,000 (because in the USA any contract for the sale of goods over US\$500 must be in writing to be enforceable). The point of the Statute of Frauds is to prevent false allegations of the existence of contracts that were never made, by requiring formal (i.e. written) evidence of the contract. Contracts that do not meet the requirements of Statute of Frauds legislation are unenforceable, but not void. However, a party unjustly enriched by an unenforceable contract may be subject to restitution for unjust enrichment. Statutes of Frauds are typically codified in state statutes covering specific types of contracts, such as contracts for the sale of real estate.

In Australia, for contracts subject to legislation equivalent to the Statute of Frauds, there is no requirement for the entire contract to be in writing, although there must be a note or memorandum evidencing the contract, which may come into existence after the contract has been formed. The note or memorandum must be signed in some way, and a series of documents may be used in place of a single note or memorandum. It must contain all material terms of the contract, 
the subject matter and the parties to the contract. In England and Wales, the Statute of Frauds is still in force, but only for guarantees, which must be evidenced in writing, although the agreement may be made orally. Certain other kinds of contract must be in writing or they are void, for instance, for sale of land under s. 52, Law of Property Act 1925.

If a contract is in a written form, and somebody signs the contract, then the person is bound by its terms regardless of whether they have read it or not, provided the document is contractual in nature. Furthermore, if a party wishes to use a document as the basis of a contract, reasonable notice of its terms must be given to the other party prior to their entry into the contract. This includes such things as tickets issued at parking stations.

Uncertainty, incompleteness and severance

If the terms of the contract are uncertain or incomplete, the parties cannot have reached an agreement in the eyes of the law. An agreement to agree does not constitute a contract, and an inability to agree on key issues, which may include such things as price or safety, may cause the entire contract to fail. However, a court will attempt to give effect to commercial contracts where possible, by construing a reasonable construction of the contract.

Courts may also look to external standards, which are either mentioned explicitly in the contract or implied by common practice in a certain field. In addition, the court may also imply a term; if price is excluded, the court may imply a reasonable price, with the exception of land, and second-hand goods, which are unique.

If there are uncertain or incomplete clauses in the contract and all options in resolving its true meaning have failed, it may be possible to sever and void just those affected clauses if the contract includes a severability clause. The test of whether a clause is severable is an objective test - whether a reasonable person would see the contract standing even without the clauses.

Contractual terms

The terms and conditions of a contract are its content. Once the so called essentialia negotii of a contract's formation are established, the question of what the parties of a contract have agreed to.

Different types of statements 
Whether a statement is a term of a contract is important because only if a promise is a term of the contract can a party sue for the breach of the contract. Statements can be split into the following types:

- Puff (sales talk): If no reasonable person hearing this statement would take it seriously, it is a puff, and no action in contract is available if the statement proves to be wrong. It may also be referred to as "puffery".

- Representation: A representation is a statement of fact made to induce another person to enter into a contract and which does induce them to enter into a contract, but it is one that the maker of the statement does not guarantee its truth. If the statement proves to be incorrect, it cannot be enforced, as it is not a term of the contract, but it may prove to be a misrepresentation, whereupon other remedies are available.

- Term: A term is similar to a representation, but the truth of the statement is guaranteed by the person who made the statement. The test is an objective test. Factors that a court may take into account in determining the nature of a statement include:

- Timing: If the contract was concluded soon after the statement was made, this is a strong indication that the statement induced the person to enter into the contract.

- Content of statement: It is necessary to consider what was said in the given context, which has nothing to do with the importance of a statement.

- Knowledge and expertise: In Oscar Chess Ltd v. Williams, a person selling a car to a second-hand car dealer stated that it was a 1948 Morris, when in fact it was a 1939 model car. It was held that the statement did not become a term because a reasonable person in the position of the car dealer would not have thought that an inexperienced person would have guaranteed the truth of the statement.

The parol evidence rule limits what things can be taken into account when trying to interpret a contract.

Terms implied in fact

1. Reasonableness and equitableness: The implied term must be reasonable and equitable. 
2. Business efficacy: The implied term must be necessary for the business efficacy of the contract. For instance, if the term simply causes the contract to operate better, that does not fit this criterion.

3. Obviousness: The term is so obvious that it goes without saying. Furthermore, there must be one and only one thing that would be implied by the parties. For example, in Codelfa Construction Pty Ltd v. State Rail Authority of New South Wales, a term regarding the inability of construction company to work three shifts a day could not be implied because it was unclear what form it would have taken.

4. Clear expression: The term must be capable of clear expression. No specific technical knowledge should be required.

5. Consistency: The implied term may not contradict an express term.

In Australia, the High Court has ruled that the test in BP Refinery applies only to formal contracts, while the test in Byrne and Frew v. Australian Airlines Ltd shall apply to informal contracts:

- Necessity: The term must be necessary to ensure reasonable or effective operation of a contract of the nature before the court.

- Consistency: The implied term may not contradict an express term (same as for formal contracts).

- Clear expression: The term must be capable of clear expression (same as for formal contracts).

- Obvious: McHugh and Gummow JJ have stated that it must also be obvious.

Terms implied in law

These are terms that have been implied into standardised relationships. The other difference between this and terms implied in fact is that the test is one of necessity; a necessary term is one where the contract is rendered worthless or nugatory if it is without it.

Terms implied by custom or trade

You are generally bound by the custom of the industry that you are in. To imply a term due to custom or trade, you must prove the existence of the custom, which must be notorious, certain, legal and reasonable

Course of dealing 
If two parties have regularly conducted business on certain terms, it may be reasonable to presume that in future dealings where there is no contract, the parties wish to incorporate the terms of the previous contracts. However, if a party wishes to incorporate terms by course of dealing, the original document must have been contractual in nature, and delivery receipts may not fit this description. In Australia, there is a further requirement that the document was procured after formation.

\section{Good faith}

It is common for lengthy negotiations to be written into a heads of agreement document that includes a clause to the effect that the rest of the agreement is to be negotiated. Although these cases may appear to fall into the category of agreement to agree, courts nowadays (at least in Australia) will imply an obligation to negotiate in good faith provided that certain conditions are satisfied - Negotiations were well-advanced and the large proportion of terms have been worked out; and

- There exists some mechanism to resolve disputes if the negotiations broke down.

The test of whether one has acted in good faith is a subjective one; the cases suggest honesty, and possibly also reasonably.

"Subject to" contracts

If a contract specifies "subject to contract", it may fall into one of three categories

1. the parties are immediately bound to the bargain, but they intend to restate the deal in a formalised contract that will not have a different effect; or

2. the parties have completely agreed to the terms, but have made the execution of some terms in the contract conditional on the creation of a formalised contract; or

3. It is merely an agreement to agree and the deal will not be concluded until the formalised contract has been drawn up.

If a contract specifies "subject to finance", it imposes obligations on the purchaser

- The purchaser must seek finance; and

- When offers of finance arrive, the purchaser must make a decision as to whether the offers of finance are suitable. 
Once again, there is an element of good faith involved.

This may also refer to contingent conditions, which come under two categories: condition precedent and condition subsequent. Conditions precedents are conditions that have to be complied with before performance of a contract. With conditions subsequent, parties have to perform until the condition is not met. Failure of a condition does not void the contract; it is just regarded as voidable.

Statutory implied terms

The rules by which many contracts are governed are provided in specialized statutes that deal with particular subjects. Most countries, for example, have statutes which deal directly with sale of goods, lease transactions, and trade practices. For example, most American states have adopted Article 2 of the Uniform Commercial Code, which regulates contracts for the sale of goods.

There are also many acts around the world which deal with specific types of transactions and businesses. For example, the states of California and New York in the U.S. have statutes that govern the provision of services to customers by health studios, and the UK has the Sale of Goods Act 1979 which governs the contracts between sellers and buyers.

Setting aside the contract

There can be three different ways in which contracts can be set aside. A contract may be deemed 'void', 'voidable' or 'unenforceable'. Voidness implies that a contract never came into existence. Voidability implies that one or both parties may declare a contract ineffective at their wish. Unenforceability implies that neither party may have recourse to a court for a remedy. Recission is a term which means to take a contract back.

Misrepresentation

Misrepresentation means a false statement of fact made by one party to another party and has the effect of inducing that party into the contract. For example, under certain circumstances, false statements or promises made by a seller of goods regarding the quality or nature of the product that the seller has may constitute misrepresentation. A finding of misrepresentation allows for a remedy of rescission and sometimes damages depending on the type of misrepresentation.

According to Gordon v. Selico it is possible to make a misrepresentation either by words or by conduct, although not everything said or done is capable of 
constituting a misrepresentation. Generally, statements of opinion or intention are not statements of fact in the context of misrepresentation. If one party claims specialist knowledge on the topic discussed, then it is more likely for the courts to hold a statement of opinion by that party as a statement of fact.

Mistake

A mistake is an incorrect understanding by one or more parties to a contract and may be used as grounds to invalidate the agreement. Common law has identified three different types of mistake in contract: unilateral mistake, mutual mistake, and common mistake.

- A unilateral mistake is where only one party to a contract is mistaken as to the terms or subject-matter. The courts will uphold such a contract unless it was determined that the non-mistaken party was aware of the mistake and tried to take advantage of the mistake. It is also possible for a contract to be void if there was a mistake in the identity of the contracting party. An example is in Lewis $v$ Avery where Lord Denning MR held that the contract can only be avoided if the plaintiff can show that at the time of agreement, the plaintiff believed the other party's identity was of vital importance. A mere mistaken belief as to the credibility of the other party is not sufficient.

- A mutual mistake is when both parties of a contract are mistaken as to the terms. Each believes they are contracting to something different. The court usually tries to uphold such a mistake if a reasonable interpretation of the terms can be found. Although a contract based on a mutual mistake in judgement does not cause the contract to be voidable by the party that is adversely affected. See Raffles v. Wichelhaus.

- A common mistake is where both parties hold the same mistaken belief of the facts. This is demonstrated in the case of Bell v. Lever Brothers Ltd., which established that common mistake can only void a contract if the mistake of the subject-matter was sufficiently fundamental to render its identity different from what was contracted, making the performance of the contract impossible.

Duress and undue influence

Duress has been defined as a "threat of harm made to compel a person to do something against his or her will or judgment; esp., a wrongful threat made by one person to compel a manifestation of seeming assent by another person to a transaction without real volition." An example is in Barton v. Armstrong, a 
decision of the Privy Council. Armstrong threatened to kill Barton if he did not sign a contract, so the court set the contract aside. An innocent party wishing to set aside a contract for duress to the person need only to prove that the threat was made and that it was a reason for entry into the contract; the onus of proof then shifts to the other party to prove that the threat had no effect in causing the party to enter into the contract. There can also be duress to goods and sometimes, the concept of 'economic duress' is used to vitiate contracts.

Undue influence is an equitable doctrine that involves one person taking advantage of a position of power over another person. The law presumes that in certain classes of special relationship, such as between parent and child, or solicitor and client, there will be a special risk of one party unduly influencing their conduct and motives for contracting. As an equitable doctrine, the court has the discretion to vitiate such a contract. When no special relationship exists, the general rule is whether there was a relationship of such trust and confidence that it should give rise to such a presumption. See Odorizzi v. Bloomfeild School District.

Incapacity

Sometimes the capacity of either natural or artificial persons to either enforce contracts, or have contracts enforced against them is restricted. For instance, very small children may not be held to bargains they have made, or errant directors may be prevented from contracting for their company, because they have acted ultra vires (beyond their power). Another example might be people who are mentally incapacitated, either by disability or drunkenness. When the law limits or bars a person from engaging in specified activities, any agreements or contracts to do so are either voidable or void for incapacity. The law on capacity can serve either a protective function or can be a way of restraining people who act as agents for others.

Illegal contracts

A contract is void if it is based on an illegal purpose or contrary to public policy. One example, from Canada is Royal Bank of Canada v. Newell. A woman forged her husband's signature on 40 cheques, totalling over $\$ \mathbf{5 8 , 0 0 0}$. To protect her from prosecution, her husband signed a letter of intent prepared by the bank in which he agreed to assume "all liability and responsibility" for the forged cheques. However, the agreement was unenforceable, and struck down by the 
courts, because of its essential goal, which was to "stifle a criminal prosecution." Because of the contract's illegality, and as a result voided status, the bank was forced to return the payments made by the husband.

In the U.S., one unusual type of unenforceable contract is a personal employment contract to work as a spy or secret agent. This is because the very secrecy of the contract is a condition of the contract (in order to maintain plausible deniability). If the spy subsequently sues the government on the contract over issues like salary or benefits, then the spy has breached the contract by revealing its existence. It is thus unenforceable on that ground, as well as the public policy of maintaining national security (since a disgruntled agent might try to reveal all the government's secrets during his/her lawsuit).

Remedies for breach of contract

A breach of contract is failure to perform as stated in the contract. There are many ways to remedy a breached contract assuming it has not been waived. Typically, the remedy for breach of contract is an award of money damages. When dealing with unique subject matter, specific performance may be ordered. As for many governments, it was not possible to sue the Crown in the U.K. for breach of contract before 1948. However, it was appreciated that contractors might be reluctant to deal on such a basis and claims were entertained under a petition of right that needed to be endorsed by the Home Secretary and Attorney-General. S.1 Crown Proceedings Act 1947 opened the Crown to ordinary contractual claims through the courts as for any other person.

\section{Damages}

There are three different types of damages.

- Compensatory damages which are given to the party which was detrimented by the breach of contract. With compensatory damages, there are two kinds of branches, consequential damages and direct damages.

- Nominal damages which include minimal dollar amounts (often sought to obtain a legal record of who was at fault).

- $\quad$ Punitive damages which are used to punish the party at fault. These are not usually given regarding contracts but possible in a fraudulent situation.

Whenever you have a contract that requires completing something, and a person informs you that it will not be completed before they begin your project, this is referred to anticipatory breach. When it is either not possible or desirable to 
award damages measured in that way, a court may award money damages designed to restore the injured party to the economic position that he or she had occupied at the time the contract was entered (known as the "reliance measure"), or designed to prevent the breaching party from being unjustly enriched ("restitution").

Specific performance

There may be circumstances in which it would be unjust to permit the defaulting party simply to buy out the injured party with damages. For example where an art collector purchases a rare painting and the vendor refuses to deliver, the collector's damages would be equal to the sum paid.

The court may make an order of what is called "specific performance", requiring that the contract be performed. In some circumstances a court will order a party to perform his or her promise (an order of "specific performance") or issue an order, known as an "injunction," that a party refrain from doing something that would breach the contract. A specific performance is obtainable for the breach of a contract to sell land or real estate on such grounds that the property has a unique value.

Both an order for specific performance and an injunction are discretionary remedies, originating for the most part in equity. Neither is available as of right and in most jurisdictions and most circumstances a court will not normally order specific performance. A contract for the sale of real property is a notable exception. In most jurisdictions it is enforceable by specific performance. However, even in this case the defenses to an action in equity (such as laches, the bona fide purchaser rule, or unclean hands) may act as a bar to specific performance.

Related to orders for specific performance, an injunction may be requested when the contract prohibits a certain action. Action for injunction would prohibit the person from performing the act specified in the contract.

Procedure

In the United States, in order to obtain damages for breach of contract or to obtain specific performance, the injured party may file a civil (non-criminal) lawsuit, usually in a state court, or petition a private arbitrator to decide the contract issues presented. 
Many contracts provide that all contract disputes must be arbitrated by the parties to the contract, rather than litigated in courts. By law, some contracts, including most securities brokerage contracts, must be arbitrated; other contracts are referred by courts as a matter of local law or policy. Arbitrated judgements are generally enforced and appealed in the same manner as ordinary court judgements; a majority of states have adopted the Uniform Arbitration Act to facilitate the enforcement of arbitrated judgements.

In England and Wales, a contract may be enforced by use of a claim, or in urgent cases by applying for an interim injunction to prevent a breach.

\section{Third Parties}

The doctrine of privity of contract means that only those involved in striking a bargain would have standing to enforce it. In general this is still the case, only parties to a contract may sue for the breach of a contract, although in recent years the rule of privity has eroded somewhat and third party beneficiaries have been allowed to recover damages for breaches of contracts they were not party to. A recent example is in England, where the Contract (Rights of Third Parties) Act 1999 was introduced.

Contractual theory

Contract theory is the body of legal theory that addresses normative and conceptual questions in contract law. One of the most important questions asked in contract theory is why contracts are enforced. One prominent answer to this question focuses on the economic benefits of enforcing bargains. Another approach, associated with Charles Fried, maintains that the purpose of contract law is to enforce promises. This theory is developed in Fried's book, Contract as Promise. Other approaches to contract theory are found in the writings of legal realists and critical legal studies theorists.

Another dimension of the theoretical debate in contract is its place within, and relationship to a the wider law of obligations. Obligations have traditionally been divided into contracts, which are voluntarily undertaken and owed to a specific person or persons, and obligations in tort which are based on the wrongful infliction of harm to certain protected interests, primarily imposed by the law, and typically owed to a wider class of persons.

Recently it has been accepted that there is a third category, restitutionary obligations, based on the unjust enrichment of the defendant at the plaintiff's 
expense. Contractual liability, reflecting the constitutive function of contract, is generally for failing to make things better (by not rendering the expected performance), liability in tort is generally for action (as opposed to omission) making things worse, and liability in restitution is for unjustly taking or retaining the benefit of the plaintiff's money or work

Compare with the US context, the Uniform Commercial Code defining "Contract" as "the total legal obligation which results from the parties' agreement" [citation needed] and does not attempt to state what act is essential to create a legal duty to perform a promise. The common law describes the circumstances under which the law will recognise the existence of rights, privilege or power arising out of a promise.

Offer

An offer is an expression of willingness to contract on certain terms, made with the intention that it shall become binding as soon as it is accepted by the person to whom it is addressed, the "offeree" [G.H. Treitel, The Law of Contract, 10th edn, p.8].

The "expression" referred to in the definition may take different forms, such as a letter, newspaper, fax, email and even conduct, as long as it communicates the basis on which the offeror is prepared to contract.

The "intention" referred to in the definition is objectively judged by the courts. The English case of Smith v. Hughes (1871) LR 6 QB 597 emphasises that the important thing is not a party's real intentions but how a reasonable person would view the situation. This is due mainly to common sense as each party would not wish to breach his side of the contract if it would make him or her culpable to damages, it would especially be contrary to the principle of certainty and clarity in commercial contract and the topic of mistake and how it affect the contract.

The classical principles are illustrated in the well-known case of Carlill $v$. Carbolic Smoke Ball Company.

Unilateral contract

The contract in Carlill v. Carbolic Smoke Ball Co was of a kind known as a unilateral contract, one in which the offeree accepts the offer by performing his or her side of the bargain. It can be contrasted with a bilateral contract, where there is an exchange of promises between two parties. In Australian Woollen 
Mills Pty Ltd v. The Commonwealth (1954), the High Court of Australia held that, for a unilateral contract to arise, the promise must be made "in return for" the doing of the act. The court distinguished between unilateral contracts from a conditional gift. The case is generally seen to demonstrate the connection between the requirements of offer and acceptance, consideration and intention to create legal relations.

Invitations to treat

An invitation to treat is not an offer, but an indication of a person's willingness to negotiate a contract. In Harvey $v$ Facey, an indication by the owner of property that he or she might be interested in selling at a certain price, for example, has been regarded as an invitation to treat (ITT). Similarly in Gibson v Manchester City Council the words "may be prepared to sell" were held to be a notification of price and therefore not a distinct offer. The courts have tended to take a consistent approach to the identification of invitations to treat, as compared with offer and acceptance, in common transactions. The display of goods for sale, whether in a shop window or on the shelves of a self-service store, is ordinarily treated as an invitation to treat (Fisher v. Bell) and not an offer. The holding of a public auction will also usually be regarded as an invitation to treat. Revocation of offer

An offeror may revoke an offer before it has been accepted, but the revocation must be communicated to the offeree, although not necessarily by the offeror. If the offer was made to the entire world, such as in Carlill's case, the revocation must take a form that is similar to the offer. However, an offer may not be revoked if it has been encapsulated in an option (see also option contract).

If the offer is one that leads to a unilateral contract, then unless there was an ancillary contract entered into that guaranteed that the main contract would not be withdrawn, the contract may be revoked at any time: see Mobil Oil Australia Ltd v. Welcome International Pty Ltd (1998) 81 FCR 475..

\section{Acceptance}

Test of acceptance

Acceptance is a final and unqualified expression of assent to the terms of an offer [G.H. Treitel, the Law of Contract, 10th edn, p.16]. It is no defense to an action based on a contract for the defendant to claim that he never intended to be bound by the agreement if under all the circumstances it is shown at trial that his 
conduct was such that it communicated to the other party or parties that the defendant had in fact agreed. Signing of a contract is one way a party may show his assent. Alternatively, an offer consisting of a promise to pay someone if the latter performs certain acts which the latter would not otherwise do (such as paint a house) may be accepted by the requested conduct instead of a promise to do the act. The performance of the requested act indicates objectively the party's assent to the terms of the offer.

The essential requirement is that there must be evidence that the parties had each from an objective perspective engaged in conduct manifesting their assent. This manifestation of assent theory of contract formation may be contrasted with older theories, in which it was sometimes argued that a contract required the parties to have a true meeting of the minds between the parties. Under the "meeting of the minds" theory of contract, a party could resist a claim of breach by proving that although it may have appeared objectively that he intended to be bound by the agreement, he had never truly intended to be bound. This is unsatisfactory, as the other parties have no means of knowing their counterparts' undisclosed intentions or understandings. They can only act upon what a party reveals objectively to be his intent. Hence, an actual meeting of the minds is not required.

This requirement of an objective perspective is important in cases where a party claims that an offer was not accepted, taking advantage of the performance of the other party. Here, we can apply the test of whether a reasonable bystander (a "fly on the wall") would have perceived that the party has impliedly accepted the offer by conduct.

Rules of acceptance

Communication of acceptance

There are several rules dealing with the communication of acceptance:

- The acceptance must be communicated: Depending on the construction of the contract, the acceptance may not have to come until the notification of the performance of the conditions in the offer as in Carlill's case, but nonetheless the acceptance must be communicated. Prior to acceptance, an offer may be withdrawn.

- An offer can only be accepted by the offeree, that is, the person to whom the offer is made. 
- An offeree is not bound if another person accepts the offer on his behalf without his authorization: see agent (law).

- It may be implied from the construction of the contract that the offeror has dispensed with the requirement of communication of acceptance.

- If the offer specifies a method of acceptance (such as by post or fax), you must accept it using a method that is no less effective than the method specified.

- $\quad$ Silence cannot be construed as acceptance: see Felthouse v. Bindley (1862) 142 ER 1037.

Correspondence with offer

The "mirror image rule" states that if you are to accept an offer, you must accept an offer exactly, without modifications; if you change the offer in any way, this is a counter-offer that kills the original offer. However, a mere request for information is not a counter-offer. It may be possible to draft an enquiry such that it adds to the

Battle of the forms

Often when two companies deal with each other in the course of business, they will use standard form contracts. Often these terms conflict (eg. both parties include a liability waiver in their form) and yet offer and acceptance are achieved forming a binding contract. The battle of the forms refers to the resulting legal dispute of these circumstances, wherein both parties recognise that an enforceable contract exists, however they are divided as to whose terms govern that contract.

Under English law, the question was raised in Butler Machine Tool Co Ltd v. Ex-Cell-O Corporation (England) Ltd [1979] WLR 401, as to which of the standard form contracts prevailed in the transaction. Denning MR preferred the view that the documents were to be considered as a whole, and the important factor was finding the decisive document; on the other hand, Lawton and Bridge LJJ preferred traditional offer-acceptance analysis, and considered that the last counter-offer prior to the beginning of performance voided all preceding offers. The absence of any additional counter-offer or refusal by the other party is understood as an implied acceptance. In US law, this principle is referred to as the last-chance doctrine.

Under the Uniform Commercial Code (UCC) Sec. 2-207(1), A definite expression of acceptance or a written confirmation of an informal agreement may constitute 
a valid acceptance even if it states terms additional to or different from the offer or informal agreement. The additional or different terms are treated as proposals for addition into the contract under UCC Sec. 2-207(2). Between merchants, such terms become part of the contract unless: a) the offer expressly limits acceptance to the terms of the offer, b) material alteration of the contract results, c) notification of objection to the additional/different terms are given in a reasonable time after notice of them is received.

Postal acceptance rule

As a rule of convenience, if the offer is accepted by post, the contract comes into existence at the moment that the acceptance was posted (Adams v. Lindsell (1818) 106 ER 250). This rule only applies when, impliedly or explicitly, the parties have in contemplation post as a means of acceptance. It excludes contracts involving land, letters incorrectly addressed and instantaneous modes of communication.

Knowledge of the offer

In Australian law, there is a requirement that an acceptance is made in reliance or persuance of an offer: see $R$ v. Clarke.

Death of offeror

The offer cannot be accepted if the offeree knows of his death. In cases where the offeree accepts in ignorance of the death, the contract may still be valid, although this proposition depends on the nature of the offer. If the contract involves some characteristic personal to the offeror, the offer is destroyed by the death.

Death of offeree

An offer is rendered invalid upon the death of the offeree: see Re Irvine.

Counter Offers

If the offeree rejects the offer, the offer has been destroyed and cannot be accepted at a future time. A case illustrative of this is Hyde v. Wrench (1840) 49 E.R. 132, where in response to an offer to sell an estate at a certain price, the plaintiff made an offer to buy at a lower price. This offer was refused and subsequently, the plaintiffs sought to accept the initial offer. It was held that no contract was made as the initial offer did not exist at the time that the plaintiff tried to accept it, the offer having been revoked by the counter offer. 
It should be noted that a mere inquiry (about terms of an offer) is not a counter offer and leaves the offer intact. The case Stevenson v. McLean (1880) 28 W.R. 916 is analogous to this situation.

Formation

A contract will be formed (assuming the other requirements are met) when the parties give objective manifestation of an intent to form the contract. Of course, the assent must be given to terms of the agreement. Usually this involves the making by one party of an offer to be bound upon certain terms, and the other parties' acceptance of the offer on the same terms.

Postal Acceptance Rule

The mailbox rule or the postal acceptance rule is a term of common law contracts which determines the timing of acceptance of an offer when mail is contemplated as the medium of acceptance. The general principle is that a contract is formed when acceptance is actually communicated to the offeror. The mailbox rule is an exception to the general principle. The mailbox rule provides that the contract is formed when the letter of acceptance is placed in the mailbox. The leading case in the mailbox rule is Henthorn v. Fraser [1892] $2 \mathrm{Ch} 77$ which was based in part on the earlier case of Adams v. Lindsell (1818) B \& Ald 681.

The mailbox rule applies only to acceptance; other letters do not take effect until the letter is delivered, as in Stevenson $v$ McLean (1880) 5 QBD 346. The implication of this is that it is possible for a letter of acceptance to be posted after a letter of revocation of the offer has been posted but before it is delivered, and acceptance will be complete at the time that the letter of acceptance was posted. For example, suppose A makes an offer to $B$ on January 1; A then decides to revoke the offer on January 2 and puts a letter in the mail to $B$ revoking the offer; however, $B$ puts a letter accepting the offer in the mail on January 3 , and does not receive A's revocation letter until January 4. The letter of revocation can be effective only when received, that is January 4. However, the contract was formed on January 3 when the letter of acceptance was posted. It is too late to revoke the offer.

Suppose that A makes an offer to $B$ on January 1, and initially $B$ intends to reject the offer on January 2 by putting a letter in the mail to $A$ rejecting the offer. However, the next day $B$ changes his mind and sends a fax to A accepting the offer. In this situation, whichever communication A receives first will govern. 
Under the mailbox rule, performance is a means of acceptance. If $A$ orders 1000 blue coathangers and $B$ ships them out, that shipment is considered to be a conveyance of acceptance of $A$ 's offer to buy the coathangers. Defective performance is also an acceptance, unless accompanied by an explanation. For example, if an orders 1000 blue coathangers and $B$ mistakenly ships 1000 red coathangers, this is still an acceptance of the contract. However, if B ships the red coathangers with a note that they sent these because they had run out of blue coathangers, this is not an acceptance, but rather an accommodation, which is a form of counter-offer.

An interesting implication of the operation of the mailbox rule is that as acceptance is complete once the letter of acceptance is posted, it makes no difference whether the offeror actually receives the letter. This was demonstrated in Byrne $v$ Van Tienhoven (1880) 5 CPD 344. If a letter of acceptance were to be lost, acceptance has still taken place. An exception to this would be if the offeree knows or has reason to know that the letter of acceptance never reached the offeror. For example, if A brings a letter of acceptance to the local post office and a sees the post office burn down, there is no acceptance.

The mailbox rule does not apply to instantaneous forms of communications. For example in Entores Ltd v Miles Far East Corporation [1955] 2 QB 327, the Court held that the mailbox rule did not apply to an acceptance by telex as the Court regarded it as an instantaneous form of communication. The general principle that acceptance takes place when communicated applies to instantaneous forms of communication. Courts have similarly held that the mailbox rule does not apply to acceptances by telephone or fax.

The courts are yet to decide whether e-mail should be regarded as an instantaneous form of communication. If the offeree were to convey acceptance by commercially unreasonable means - by cross-country pony express, for example - the acceptance would not be effective until it had actually been received.

A letter is regarded as "posted" only when it is in the possession of the Post Office; this was established in the case of Re London \& Northern Bank [1900] 1 Ch 220. A letter of acceptance is not considered "posted" if it is handed to an agent to deliver, such as a courier. 
The mailbox rule does not apply to option contracts or irrevocable offers where acceptance is still effective only upon receipt. This is because the offeree no longer needs protection against subsequently mailed revocations of the offer.

\section{UNCITRAL Model Law of Electronic Commerce}

Many Nations have enacted legislation based on the UNCITRAL Model Law of Electronic Commerce. Such legislation is often entitled the Electronic Transactions Act. Among other issues, this legislation deals a default rule for the time that email (electronic communications) is sent and when it is received. However it is mistaken to suggest that it deals with an electronic clarification of the postal acceptance rule for electronic communications. There are two schools of thought.

(1) Ask if the postal acceptance rule applies to emails (electronic communications). If your answer is yes, then the relevant Electronic Transaction Act (ETA) can help. The postal acceptance rule states that there is a contract when posted - so we should apply the "sent" rule under the ETA. If the answer is no; then either apply the "received" rule under the ETA or ignore it and use the contract rule of communication.

(2) Instead, treat the Electronic Transactions Act as an intended substitute and statutory replacement of the postal acceptance rule; in which case the "received" rule should apply. The problem with this second school of thought is that there is nothing in the Model Law of neither Electronic Commerce, nor the ETAs which suggests that it was intended to replace the postal acceptance rule. We are still waiting for a court to decide. The UNCITRAL rules on time of sending and receiving are:

(1) Unless otherwise agreed between the originator and the addressee, the dispatch of a data message occurs when it enters an information system outside the control of the originator or of the person who sent the data message on behalf of the originator.

(2) Unless otherwise agreed between the originator and the addressee, the time of receipt of a data message is determined as follows:

(a) If the addressee has designated an information system for the purpose of receiving data messages, receipt occurs:

(I) at the time when the data message enters the designated information system; or 
(ii) If the data message is sent to an information system of the addressee that is not the designated information system, at the time when the data message is retrieved by the addressee;

(b) If the addressee has not designated an information system, receipt occurs when the data message enters an information system of the addressee.

Invitation to treat

In contract law, an invitation to treat (invitation to bargain in the US) is an action by one party which may appear to be a contractual offer but which is actually inviting others to make an offer of their own. The distinction is important because if a legitimate contractual offer is accepted by another, a binding contract is immediately formed and the terms of the original offer cannot be further negotiated without both parties' consent. An invitation to treat may be seen as a request for expressions of interest.

The clearest example of an invitation to treat is a tender (or bidding in the US) process. This was illustrated in the case of Spencer $v$ Harding (1870) LR 5 CP 561, where the defendants offered to sell by tender their stock and the court held that they had not undertaken to sell to the person who made the highest tender, but were inviting offers which they could then accept or reject as they saw appropriate. In certain circumstances though, an invitation for tenders may be an offer. The clearest example of this was seen in Harvela Investments Ltd $v$ Royal Trust of Canada (CI) Ltd [1986] AC 207, where the defendants had made it clear that they were going to accept the highest tender; the court held that this was an offer which was accepted by the person who made the highest tender and that the defendants were in breach of contract by not doing so.

An auction may be more ambiguous. Generally an auction may be seen as an invitation to treat, with the property owner asking for offers of a certain amount and then selecting which to accept as illustrated in Payne v Cave (1789) 3 TR 148. However, if it is stated by the owner that there is no reserve price or that there is a reserve price beyond which offers will be accepted then the auction is most likely a contractual offer which is accepted by the highest bidder; this was affirmed in the Court of Appeal in Barry v Davies [2000] 1 WLR 1962.

A shop owner displaying their goods for sale is generally making an invitation to treat (Pharmaceutical Society of Great Britain v Boots Cash Chemists [1953] 1 QB 401). They are not obliged to sell the good to anyone who is willing to pay for 
them, even if additional signage such as "special offer" accompanies the display of the good. (But see bait and switch.) This distinction was legally relevant in Fisher v Bell [1961] 1 QB 394, where it was held that displaying a flicknife for sale in a shop did not contravene legislation which prohibited offering for sale such a weapon. The distinction also means that if a shop mistakenly displays a good for sale at a very low price it is not obliged to sell it for that amount [1].

Generally, advertisements are invitations to treat, so the person advertising is not compelled to sell to every customer. In Partridge v Crittenden [1968] 1 WLR 1204, it was held that where the appellant advertised to sell wild birds, was not offering to sell them. Lord Parker CJ commented that it did not make "business sense" for advertisements to be offers, as the person making the advertisement may find himself in a situation where he would be contractually obliged to sell more goods than he actually owned. In certain circumstances however, an advertisement can be an offer, a well known example being the case of Carlill $v$ Carbolic Smoke Ball Company [1893] 1 QB 256, where it was held that the defendants, who advertised that they would pay anyone who used their product in the prescribed manner and caught the flu $£ 100$ and said that they had deposited $£ 1,000$ in the bank to show their good faith, has made an offer to the whole world and were contractually obliged to pay $£ 100$ to whoever accepted it by performing the requested acts.

\section{Consideration}

Consideration is something that is done or promised in return for a contractual promise. For example, in a promise between $A$ and $B$ for the sale of A's car to B, $B$ 's payment of the price of the car (or promise to do so) is the consideration for A's promise. Consideration is a central concept in the common law of contracts. Under classical contract theory, consideration is required for a contract to be enforceable. Service contracts and, in the United States, other contracts not governed by the Uniform Commercial Code, generally require consideration for a contract modification to be binding on the parties, because of the preexisting duty rule. Consideration is what must be given up by each party when making an agreement; this may be by means of doing or not doing an act or just promising to do or not do an act. Consideration can be definded as being a benefit to one party while being a detriment to the other one at the same time. 
In order to meet consideration's requirements, a contract must fulfill three elements. First, there must be a bargain regarding terms of an exchange. Second, there must be a mutual exchange. In other words, both parties must get something out of the contract. Third, the exchange must be something of value. An example of this is the renting of an apartment. The landlord and tenant come together to discuss the terms of the exchange (most of the time, the leasing is outlined in a contract). Thus, they have fulfilled the first requirement of consideration. To meet the second element, there must be a mutual exchange. In this case, the landlord provides housing, while the tenant provides rent payment. Third, the bargain terms must be of value. The apartment is worth what the tenant hands over each month. Therefore, this contract has met its consideration requirement, because it fits all elements of consideration...

Defenses

Modern contract theory has also permitted remedies on alternate theories such as promissory estoppel.

Promissory estoppel or, doctrine of detrimental reliance, is only able to be applied when: 1. the promisor's promise lacks consideration. 2. The promisor expects the promisee will rely only on that promise. 3. The promisee does rely on the promise and 4. Injustice can only be avoided by enforcing what was promised.

\section{Consideration theories}

There are two common theories that attempt to explain consideration. The first is the "benefit-detriment theory", in which a contract must be either to the benefit of the promisor or to the detriment of the promisee to constitute consideration. The second is the "bargain theory", in which the parties subjectively view the contract to be the product of an exchange or bargain. The bargain theory has largely replaced the benefit-detriment theory in modern contract theory, but judges often cite both and unknowingly confuse the two models in their decisions. These theories usually overlap; in standard contracts, such as a contract to buy a car, there will be both an objective benefit and detriment (the buyer experiences a benefit by acquiring the car; the seller experienced a detriment by losing a car) and the subjective experience of entering into a bargain. However, there are certain contracts which satisfy one but not the other. For instance, a deal in which the promisee feels subjectively 
relieved, but hasn't actually gained any legal rights, might satisfy the bargain theory but not the benefit-detriment theory. Alternately, a deal in which an actor takes detrimental actions possibly in reaction to an offer, without having viewed the deal as a bargain, wouldn't be viewed as a contract under the law.

The main purpose of the shift from benefit-detriment to bargain theory is to reconcile consideration theory with other aspects of contract theory. For instance, courts will not inquire as to the adequacy of consideration. If someone honestly dislikes their car and wants to sell it for fifty dollars, the law will not consider this an invalid deal. In some jurisdictions, contracts calling for such nominal or "peppercorn" consideration will be upheld unless a particular contract is deemed unconscionable. However, in other jurisdictions, the court will reject "consideration" that was not truly bargained for. Occasionally the courts in these jurisdictions may refer to "adequate" or "valuable" consideration, but in reality the court is not examining the adequacy of consideration, but whether it was bargained for. The traditional notion that courts won't look into the adequacy of consideration, an ancient notion in the English common law, doesn't square with the benefit-detriment theory (in which courts are implicitly analyzing if the parties are receiving a sufficient benefit) but does square with the bargain theory (in which only the subjective intentions of the parties are considered).

For example, in Fischer v. Union Trust Co., 101 N.W. 852, the court held that $\$ 1.00$ paid in exchange for the sale of real property within the city of Detroit in 1902 was not "bargained for" by the seller, and thus the transaction was void. The point was NOT that the amount of money involved was too small to be adequate consideration, but that the seller did not convey the property in exchange for the buyer's promise to pay $\$ \mathbf{1 . 0 0}$. There was no consideration, not because $\$ 1.00$ was too small an amount to "count", but because the $\$ 1.00$ offered to the seller by the buyer did not induce the seller to part with the property.

There are three main purposes cited for the consideration requirement. The first is the cautionary requirement - parties are more likely to look before they leap when making a bargain than when making an off-the-cuff promise of a gift. The second is the evidentiary requirement - parties are more likely to commemorate, or at least remember, a promise made due to a bargaining process. The third is the channeling requirement - parties are more likely to coherently stipulate their 
specific desires when they are forced to bargain for them. Each of these rationales ensures that contracts are made by serious parties and are not made in error.

Certain other stipulations regarding consideration include the following:

- Past consideration is not valid. Something that is already done is done, and it does not change the legal position of the promisor. Any goods or services to be exchanged must be exchanged at or after the time of contract formation. However, a promise to pay a pre-existing debt or obligation is indeed enforceable.

- Preexisting duty does not count as consideration.

- An illusory promise, or one which the promisor actually has no obligation to keep, does not count as consideration. The promise must be real and unconditional. This doctrine rarely invalidates contracts; it is a fundamental doctrine in contract law that courts should try to enforce contracts whenever possible. Accordingly, courts will often read implied-in-fact or implied-in-law terms into the contract, placing duties on the promisor. For instance, if a promisor promises to give away a third of his earnings for the year, he has no actual obligation to do anything; if he earns nothing.

Defenses against formation

\section{Non EST factum}

Latin for "it is not [my] deed" - is a doctrine in contract law that allows a signing party to escape performance of the agreement. A claim of non est. factum means that the signature on the contract was signed by mistake, without knowledge of its meaning, but was not done so negligently. A successful plea would make the contract voidable.

Illusory promise

In contract law, an illusory promise is one that courts will not enforce. This is in contrast with a contract, which is a promise that courts will enforce. A promise may be illusory for a number of reasons. In common law countries this usually results from failure or lack of consideration (see also consideration under English law). 
Illusory promises are so named because they merely hold the illusion of contract. For example, a promise of the form, "I will give you ten dollars if I feel like it," is purely illusory and will not be enforced as a contract.

It is a general principle of contract law that courts should err on the side of enforcing contracts. Parties entering into the arrangement presumably had the intention of forming an enforceable contract, and so the court should attempt to follow this intention. Methods of doing so include:

- Implied-in-law "good faith" terms

- Implied-in-fact terms

- Bargaining for a chance

Implied-in-law "good faith" terms

Many contracts include "satisfaction clauses", in which a promisor can refuse to pay if he isn't subjectively satisfied with the promisee's performance. Strictly speaking, this is an illusory promise, since the promisor has no actual legal burden to pay if he chooses not to. However, courts will generally imply in law that the promisor must act in good faith, and only reject the deal if he is genuinely dissatisfied. As another example, if a contract promises a promisee a certain percentage of the proceeds of a promisor's business activities, this is illusory, since the promisor doesn't have to do anything - any percent of zero is zero. However, courts will imply that the promisor promised to use reasonable efforts to try to make money, and cite him for breach of contract if he does absolutely nothing. The U.C.C. in contracts exclusive to both sides requires "best efforts" in such contracts. This is either read to be the same as a good faith effort, but is seen by some courts as a higher duty.

Implied-in-fact terms

Judges will often infer terms into the contract that the parties did not explicitly cite. For instance, in the "satisfaction clause" case, judges might infer that the parties intended a "reasonableness test" - that the clause could be satisfied if a reasonable person would be satisfied by the promisee's performance, regardless of whether the promisor himself asserts he is satisfied. (This interpretation is often used in cases in which a performance can be objectively evaluated, such as with the construction of a warehouse; the implied-in-law interpretation above is preferred where satisfaction is more subjective, as with the painting of a portrait.) 
Bargaining for a chance

Many judges would consider the "bargaining for a percentage of the proceeds" example above an enforceable contract, even without an implied-in-fact or implied-in-law good faith term. They would view the opportunity to enter into a business relationship to itself be acceptable consideration. Put differently, the mere possibility that the promisor would do business is a valuable product of the bargain, even if he doesn't do anything. Of course, if the promisor entered into the relationship purely with the intent of fraudulently harming the promisee, he could be cited for fraud or bad faith principles which apply to all contracts.

Statute of frauds

The statute of frauds refers to a statute (i.e., statutory law), or a provision in a statute, in many common law jurisdictions that requires certain kinds of contracts to be done in writing and to be signed by the party against whom enforcement is sought. In a number of civil law jurisdictions, there are similar requirements in their civil codes.

The term statute of frauds comes from an English statutory law (29 Car. II c. 3) passed in 1677 and more properly called the Statute of Frauds and Perjuries.

The writing that the Statute requires is a precondition to maintaining a suit for breach of contract (or other obligation). However, the Statute is used as a defense, which defense is waived if the person against whom enforcement is sought fails to rise in a timely manner. Thus, the burden of showing evidence that such writing exists only comes into play when a Statute of Frauds defense is raised by the defendant. A defendant who admits the existence of the contract in his pleadings, under oath in a deposition or affidavit, or at trial, may not use the defense.

A statute of frauds defense may also be defeated by a showing of part performance. If the parties have taken action in reliance on the agreement, a court may uphold the contract despite a violation of the statute of frauds because the parties' subsequent actions verify that a contract existed. Courts are wary of parties misusing the statute of frauds as a "get out of jail free card" in breach of contract actions.

Under common law, the Statute of Frauds also applies to contract modification for example, suppose party A makes an oral agreement to lease a house from party $B$ for 9 months. Immediately after taking possession party A decides that 
he really likes the place, and makes an oral offer to party $B$ to extend the term of the lease by 6 months. Although neither agreement alone comes under the Statute of Frauds, the extension modifies the original contract to make it a 15month lease, thereby bringing it under the Statute. In practice, this works in reverse as well - an agreement to reduce the lease from 15 months to 9 months would not require a writing. However, almost all jurisdictions have enacted statutes that require writing in such situations. The Uniform Commercial Code abrogated this requirement for contract modification, discussed below.

Traditionally, the statute of frauds requires a writing signed by the party against whom enforcement is sought in the following circumstances:

- Contracts in consideration of marriage.

- Contracts which cannot be performed within one year.

- Contracts for the sale of an interest in land.

- Contracts by the executor of a will to pay a debt of the estate with his own money.

- Under the Uniform Commercial Code (article 2, section 201) in the United States, contracts for the sale of goods where the price equals $\$ 500.00$ or more (with the exception of professional merchants performing their normal business transactions, or any custom-made items designed for one specific buyer) [1]. The most recent revision of UCC 2-201 increases the triggering point for the UCC Statute of Frauds to $\$ \mathbf{5 , 0 0 0 ,}$, but as of 2006 no U.S. state has adopted revised Section 201.

- Contracts in which one party becomes a surety (acts as guarantor) for another party's debt or other obligation.

Uniform Commercial Code

In the United States, the application of the statute of frauds to dealings between merchants has been modified by provisions of the Uniform Commercial Code, which is a statute that has been enacted by every state (except Louisiana). Uniform Commercial Code $§ 1-206$ [2] sets out a "catch-all" statute of frauds for personal property not covered by any other specific law, stating that a contract for the sale of such property where the purchase price exceeds $\$ 500.00$ is not enforceable unless memorialized by a signed writing. This section, however, is rarely invoked in litigation. 
Interestingly, with respect to securities transactions, the Uniform Commercial Code (section 8-113) has abrogated the statute of frauds. The drafters of the most recent revision commented that "with the increasing use of electronic means of communication, the statute of frauds is unsuited to the realities of the securities business."

\section{Exceptions}

An agreement may be enforced even if it does not comply with the statute of frauds in the following situations:

- Merchant's Firm Offer, under the UCC. If one merchant sends a writing sufficient to satisfy the statute of frauds to another merchant, the merchant has reason to know of the contents of the sent confirmation and the receivor does not object to the confirmation within 10 days, the confirmation is good to satisfy the statute as to both parties.

- Admission of the existence of a contract by the defendant under oath,

- Part Performance of the contract. The agreement is enforceable up to the amount already paid, delivered, etc.

- The goods were specially manufactured for the buyer and the seller either 1) began manufacturing them, or 2 ) entered into a third party contract for their manufacture, and the manufacturer cannot without undue burden sell the goods to another person in the seller's ordinary course of business-- for example, $t$ shirts with a baseball team logo or wall-to-wall carpeting for an odd-sized room. Duress

Duress in the context of contract law is a common law defence, and if you are successful in proving that the contract is vitiated by duress, you can rescind the contract, since it is then voidable.

Duress has been defined as a "threat of harm made to compel a person to do something against his or her will or judgment; esp., a wrongful threat made by one person to compel a manifestation of seeming assent by another person to a transaction without real volition." - Black's Law Dictionary (8th ed. 2004)

Duress in contract law falls into two broad categories:

- $\quad$ Physical duress

- $\quad$ Economic duress

Physical duress

Duress to the person 
In Barton v. Armstrong [1976] AC 104, a decision of the Privy Council, Armstrong threatened to kill Barton if he did not sign a contract, which was set aside due to duress to the person. An innocent party wishing to set aside a contract for duress to the person need only to prove that the threat was made and that it was a reason for entry into the contract; the onus of proof then shifts to the other party to prove that the threat had no effect in causing the party to enter into the contract. Duress can also be made by social influence.

Duress to goods

In such cases, one party refuses to release the goods belonging to the other party until the other party enters into a contract with them. For example, in Hawker Pacific Pty Ltd v Helicopter Charter Pty Ltd (1991) 22 NSWLR 298, the contract was set aside after Hawker Pacific's threats to withhold the helicopter from the plaintiff unless further payments were made for repairing a botched paint job.

Economic duress

Although hard bargaining occurs legitimately in commercial situations, there is a point where it becomes economic duress. Putting aside issues of consideration, this often involves one party threatening to breach an existing contract between the two parties unless the innocent party agrees to enter into another contract. The contract is voidable if the innocent party can prove that it had no other practical choice (as opposed to legal choice) but to agree to the contract.

Undue influence

Undue influence (as a term in jurisprudence) is an equitable doctrine that involves one person taking advantage of a position of power over another person. It is where free will to bargain is not possible.

If undue influence is proved in a contract (at least in Australia), the contract is voidable by the innocent party, and the remedy is rescission. There are two categories to consider:

- $\quad$ Presumed undue influence

- $\quad$ Actual undue influence

Presumed undue influence

First subgroup

In the first subgroup, the relationship falls in a class of relationships that as a matter of law will raise a presumption of undue influence. Such classes include:

- $\quad$ Parent/child 
- Guardian/ward

- $\quad$ Priest/member of parish

- $\quad$ Solicitor/client

- Doctor/patient

In such cases, the onus of proof lies on a doctor, say, to disprove undue influence on a patient.

Second subgroup

The second subgroup covers relationships that do not fall into the first subgroup, but on the facts of case, there was an antecedent relationship between the parties that led to undue influence. The test is one of whether there was a relationship of such trust and confidence that it should give rise to such a presumption (see Johnson v. Buttress (1936) 56 CLR 113).

Actual undue influence

An innocent party may also seek to have a contract set aside for actual undue influence, where there is no presumption of undue influence, but there is evidence that the power was unbalanced at the time of the signing of the contract.

Undue influence in probate law

"Undue Influence" is the most common ground for will contests and is often accompanied by a capacity challenge. In probate law, it is generally defined as a testator's loss of free agency regarding property disposition through contemporaneous psychological domination by an advisor which results in an excessive benefit to the advisor. It is important to note that "undue influence" is only an issue when the advisor is benefiting, not when advisor is getting a benefit for someone else; in that case it would be considered fraud. In litigation most jurisdictions place the burden of proving undue influence on the party challenging the will.

Lack of capacity to contract

The capacity of both natural and artificial persons determines whether they may make binding amendments to their rights, duties and obligations, such as getting married or merging, entering into contracts, making gifts, or writing a valid will. Capacity is an aspect of status and both are defined by a person's personal law: 
- for natural persons, the law of domicile or lex domicilii in common law states, and either the law of nationality or lex patriae, or of habitual residence in civil law states;

- for artificial persons, the law of the place of incorporation, the lex incorporationis for companies while other forms of business entity derive their capacity either from the law of the place in which they were formed or the laws of the states in which they establish a presence for trading purposes depending on the nature of the entity and the transactions entered into.

When the law limits or bars a person from engaging in specified activities, any agreements or contracts to do so are either voidable or void for incapacity. Sometimes such legal incapacity is referred to as incompetence. For comparison, see Competence (law).

Discussion

As an aspect of the social contract between a state and its citizens, the state adopts a role of protector to the weaker and more vulnerable members of society. In public policy terms, this is the policy of parens patriae. Similarly, the state has a direct social and economic interest in promoting trade so, it will define the forms of business enterprise that may operate within its territory and lay down rules that will allow both the businesses and those that wish to contract with them a fair opportunity to gain value. This system worked well until social and commercial mobility increased. Now persons routinely trade and travel across state boundaries (both physically and electronically), so the need is to provide stability across state lines given that laws differ from one state to the next. Thus, once defined by the personal law, persons take their capacity with them like a passport whether or however they may travel. In this way, a person will not gain or lose capacity depending on the accident of the local laws, e.g. if A does not have capacity to marry her cousin under her personal law (a rule of consanguinity), she cannot evade that law by travelling to a state that does permit such a marriage (see nullity).

Natural persons

Standardised classes of person have had their freedom restricted. These limitations are justified exceptions to the general policy of freedom of contract and the detailed human and civil rights that a person of ordinary capacity might enjoy. Hence, for example, freedom of movement may be modified; the right to 
vote may be withdrawn, etc. As societies have developed more equal treatment based on gender, race and ethnicity, many of the older incapacities have been removed. For example, English law used to treat married women as lacking the capacity to own property or act independently of their husbands (the last of these rules was repealed by the Domicile and Matrimonial Proceedings Act 1973 which removed the wife's domicile of dependency for those marrying after 1974, so that a husband and wife could have different domiciles).

- Infancy

The definition of an infant or minor varies, each state reflecting local culture and prejudices in defining the age of majority, marriageable age, voting age, etc. In many jurisdictions, legal contracts, in which (at least) one of the contracting parties in a minor, are voidable by the minor. For a minor to undergo medical procedure, consent is determined by the minor's parent(s) or legal guardian(s). The right to vote in the United States is currently set at 18 years, while the right to buy and consume alcohol is often set at 21 years by U.S. state law. Some laws, such as marriage laws, may differentiate between the sexes and allow women to marry younger. There are instances in which a person may be able to gain capacity earlier than the prescribed time through a process of emancipation. Conversely, many states allow the inexperience of childhood to be an excusing condition to criminal liability and set the age of criminal responsibility to match the local experience of emerging behavioural problems (see doli incapax). For sexual crimes, the age of consent determines the potential liability of adult accused.

As an example of liability in contract, the law in most of Canada provides that an infant is not bound by the contracts he or she enters into except for the purchase of necessaries and for beneficial contracts of service. Infants must pay fair price only for necessary goods and services. However, the British Columbia Infants Act (RSBC 1996 c.223) declares all contracts, including necessities and beneficial contracts of service are unenforceable against an infant. Only student loans and other contracts made specifically enforceable by statute will be binding on infants in that province.

In contracts between an adult and an infant, adults are bound but infants may escape contracts at their option (i.e. the contract is voidable). Infants may ratify a contract on reaching age of majority. In the case of executed contracts, when 
the infant has obtained some benefit under the contract, he/she cannot avoid obligations unless what was obtained was of no value. Upon repudiation of a contract, either party can apply to the court. The court may order restitution, damages, or discharge the contract. All contracts involving the transfer of real estate are considered valid until ruled otherwise.

- Insanity, mental illness, or mental/medical condition

Individuals may have an inherent physical condition which prevents them from achieving the normal levels of performance expected from persons of comparable age, or their ability to match current levels of performance may be caused by contracting an illness. Whatever the cause, if the resulting condition is such that individuals cannot care for themselves, or may act in ways that are against their interests, those persons are vulnerable through dependency and deserve the protection of the state against the risks of abuse or exploitation. Hence, any agreements that were made are voidable, and a court may declare that person a ward of the state and grant power of attorney to an appointed legal guardian (in the UK, this is a specific function of the Court of Protection).

This sort of problem sometimes arises when people suffer some form of medical problem such as unconsciousness, coma, extensive paralysis, or delirious states, from accidents or illnesses such as strokes, or often when older people become afflicted with some form of medical/mental disability such as Huntington's disease, Alzheimer's disease, Lewy body disease, or similar dementia. Such persons are often unable to consent to medical treatment and otherwise handle their financial and other personal matters. If the afflicted person has prepared documents beforehand about what to do in such cases, often in a revocable living trust or related documents, then the named legal guardian may be able to take over their financial and other affairs. If the afflicted person owns his/her property jointly with a spouse or other able person, the able person may be able to take over many of the routine financial affairs. Otherwise, it is often necessary to petition a court, such as a probate court, that the afflicted person lacks legal capacity and allow a legal guardian to take over their financial and personal affairs. Procedures and court review have been established, dependent on the area of jurisdiction, to prevent exploitation of the incapacitated person by the guardian. The guardian periodically provides a financial accounting for court review. 
In the Criminal Law, the traditional common law M'Naghten Rules excused all persons from liability if they did not understand what they were doing or, if they did, that they did not know it was wrong. The consequences of this excuse were that those accused were detained indefinitely or until the medical authorities certified that it was safe to release them back into the community. This consequence was felt to be too draconian and so statutes have introduced new defences that will limit or reduce the liability of those accused of committing offences if they were suffering from a mental illness at the relevant time (see the insanity and mental disorder defences).

- Drunkenness/drug abuse

Although individuals may have consumed a sufficient quantity of intoxicant or drug to reduce or eliminate their ability to understand exactly what they are doing, such conditions are self-induced and so the law does not generally allow any defence or excuse to be raised to any actions taken while incapacitated. The most generous states do permit individuals to repudiate agreements as soon as sober, but the conditions to exercising this right are strict.

- Bankruptcy

If individuals find themselves in a situation where they can no longer pay their debts, they lose their status as creditworthy and become bankrupt. States differ on the means whereby their outstanding liabilities can be treated as discharged and on the precise extent of the limits that are placed on their capacities during this time but, after discharge, they are returned to full capacity. In the United States, some states have spendthrift laws under which an irresponsible spender may be deemed to lack capacity to enter into contracts (in Europe, these are termed prodigality laws) and both sets of laws may be denied extraterritorial effect under public policy as imposing a potentially penal status on the individuals affected.

- $\quad$ Enemy aliens and/or terrorists

During times of war or civil strife, a state will limit the ability of its citizens to offer help or assistance in any form to those who are acting againsts the interests of the state. Hence, all commercial and other contracts with the "enemy", including terrorists, would be considered void or suspended until a cessation of hostilities is agreed.

Business entities 
- Corporations

The extent of an artificial person's capacity depends on the law of the place of incorporation and the enabling provisions included in the constitutive documents of incorporation. The general rule is that anything not included in the corporation's capacity, whether expressly or by implication, is ultra vires, i.e. "beyond the power" of the corporation, and so may be unenforceable by the corporation, but the rights and interests of innocent third parties dealing with the corporations are usually protected.

- General and limited partnerships

There is a clear division between the approaches of states to the definition of partnerships. One group of states treats general and limited partnerships as aggregate. In terms of capacity, this means that they are no more than the sum of the natural persons who conduct the business. The other group of states allows partnerships to have a separate legal personality which changes the capacity of the "firm" and those who conduct its business and makes such partnerships more like corporations.

- Unions

In some states, trade unions have limited capacity unless any contract made relates to union activities.

- Insolvency

When a business entity becomes insolvent, an administrator, receiver, or other similar legal functionary may be appointed to determine whether the entity shall continue to trade or be sold so that the creditors may receive all or a proportion of the money owing to them. During this time, the capacity of the entity is limited so that its liabilities are not increased unreasonably and to the detriment of the existing creditors.

Contract interpretation

Parol evidence rule

The parol evidence rule enacts a principle of the common law of contracts that presumes that a written contract embodies the complete agreement between the parties involved. The rule therefore generally forbids the introduction of extrinsic evidence (i.e., evidence of communications between the parties which is not contained in the language of the contract itself) which would change the terms of a later written contract. 
In order for the rule to be effective, the contract in question must be an integrated writing; it must, in the judgment of the court, be the final agreement between the parties (as opposed to a mere draft, for example). One way to ensure that the contract will be found integration is through the inclusion of a merger clause, which recites that the contract is, in fact, the whole agreement between the parties. However, many modern cases have found merger clauses to be only a rebuttable presumption.

An integrated agreement is either a partial or complete integration. If it contains some, but not all, of the terms as to which the parties have agreed then it is a partial integration. This means that the writing was a final agreement between the parties (and not mere preliminary negotiations) as to some terms, but not as to others. On the other hand, if the writing were to contain all of the terms as to which the parties agreed, then it would be a complete integration. The importance of this distinction is relevant to what evidence is excluded under the parol evidence rule. For both complete and partial integrations, any evidence contradicting the writing is excluded under the parol evidence rule. However, for a partial integration, terms that do not contradict the writing but merely add to it is not excluded.

There are a number of exceptions to the parol evidence rule. Extrinsic evidence can always be admitted for the following purposes:

- To work out the subject matter of the contract.

- To resolve an ambiguity in the contract. [1]

- To show that an unambiguous term in the contract is in fact a mistaken transcription of a prior valid agreement. Such a claim must be established by clear and convincing evidence, and not merely by the preponderance of the evidence.

- To show fraud, duress, mistake, or illegal purpose on the part of one or both parties.

- To show that consideration has not actually been paid. For example, if the contract states that $A$ has paid $B \$ 1,000$ in exchange for a painting, $B$ can introduce evidence that $\mathrm{A}$ had never actually conveyed the $\$ 1,000$.

- $\quad$ To identify the parties, especially if the parties have changed names.

- To imply or incorporate a term of the contract. 
In order for evidence to fall within this rule, it must involve either (1) a written or oral communication made prior to execution of the written contract; or (2) an oral communication made contemporaneous with execution of the written contract. Evidence of a later communication will not be barred by this rule, as it is admissible to show a later modification of the contract (although it might be inadmissible for some other reason, such as the Statute of Frauds. Similarly, evidence of a collateral agreement - one that would naturally and normally be included in a separate writing - will not be barred. For example, if a contracts with $B$ to paint $B$ 's house for $\$ \mathbf{1 , 0 0 0 ,} B$ can introduce extrinsic evidence to show that $A$ also contracted to paint $B$ 's storage shed for $\$ 100$. The agreement to paint the shed would logically be in a separate document from the agreement to paint the house.

Though its name suggests that it is a procedural evidence rule, the consensus of courts and commentators is that the parol evidence rule constitutes substantive contract law.

Additional information on the parol evidence rule may be found in Restatement 2d of Contracts $\$ 213$.

Contract of adhesion

A standard form contract (sometimes referred to as an adhesion contract or boilerplate contract) is a contract between two parties that does not allow for negotiation, i.e. take it or leave it. It is often a contract that is entered into between unequal bargaining partners, such as when an individual is given a contract by the salesperson of a multinational corporation. The consumer is in no position to negotiate the standard terms of such contracts and the company's representative often does not have the authority to do so.

Theoretical issues

There is some debate on a theoretical level whether, and to what extent, courts should enforce standard form contracts. On the one hand they undeniably fulfill an important efficiency role in society. Standard form contracting reduces transaction costs substantially by precluding the need for buyers and sellers of goods and services to negotiate the many details of a sale contract each time the product is sold. On the other hand, there is the potential for inefficient, and even unjust, terms to be accepted by those signing these contracts. Such terms might be seen as unjust if they allow the seller to avoid all liability or unilaterally 
modify terms or terminate the contract [1]. They might be inefficient if they place the risk of a negative outcome, such as defective manufacturing, on the buyer who is not in the best position to take precautions. There are a number of reasons why such terms might be excepted [2]:

- Standard form contracts are rarely read. Lengthy boilerplate terms are often in small print and written in complicated legal language which often seems irrelevant. The prospect of a buyer finding any useful information from reading such terms is correspondingly low. Even if such information is discovered the consumer is in no position to bargain as the contract is presented on a "take it or leave it" basis. Coupled with the often large amount of time needed to read the terms, the expected payoff from reading the contract is low and few people would be expected to read it. [Citation needed]

- $\quad$ Access to the full terms may be difficult or impossible before acceptance. Often the document being signed is not the full contract; the purchaser is told that the rest of the terms are in another location. This reduces the likelihood of the terms being read and in some situations, such as software end user license agreements, can only be read after they have been notionally accepted by purchasing the good.

- Boilerplate terms are not salient. The most important terms to purchasers of a good are generally the price and the quality, which are generally understood before the contract of adhesion is signed. Terms relating to events which have very small probabilities of occurring or which refer to particular statutes or legal rules do not seem important to the purchaser. This further lowers the chance of such terms being read and also means they are likely to be ignored even if they are read.

- There may be social pressure to sign. Standard form contracts are signed at a point when the main details of the transaction have either been negotiated or explained. Social pressure to conclude the bargain at that point may come from a number of sources. The salesperson may imply that the purchaser is being unreasonable if they read or question the terms, saying that they are 'just something the lawyers want us to do' or that they are wasting their time reading them. If the purchaser is at the front of a queue (for example at an airport car rental desk) there is additional pressure to sign quickly. Finally, if there has been negotiation over price or particular details then concessions given by the 
salesperson may be seen as a gift which socially obliges the purchaser to respond by being co-operative and concluding the transaction.

- Standard form contracts may exploit unequal power relations. If the good which is being sold using a contract of adhesion is one which is essential or very important for the purchaser to buy (such as a rental property or a needed medical item) then the purchaser might have no choice but to accept the terms. This problem may be mitigated if there are many suppliers of the good who can potentially offer different terms (see below).

Some contend that in a competitive market, consumers have the ability to shop around for the supplier who offers them the most favorable terms and are consequently able to avoid injustice. As noted, however, many people do not read or understand the terms so there might be very little incentive for a firm to offer favorable conditions as they would gain only a small amount of business from doing so. Even if this is the case, it is argued by some that only a small percentage of buyers need to actively read standard form contracts for it to be worthwhile for firms to offer better terms if that group is able to influence a larger number of people by affecting the firm's reputation.

Another factor which might mitigate the effects of competition on the content of contracts of adhesion is that, in practice, standard form contracts are usually drafted by lawyers instructed to construct them so as to minimize the firm's liability and not by managers making competitive decisions. Sometimes the contracts are written by an industry body and distributed to firms in that industry, increasing homogeneity of the contracts and reducing consumer's ability to shop around.

Common law status

As a general rule, the common law treats standard form contracts as any other contract. Signature or some other objective manifestation of intent to be legally bound will bind the signor to the contract whether or not they read or understood the terms. The reality of standard form contracting, however, means that many common law jurisdictions have developed special rules with respect to them. In general, courts will interpret standard form contracts contra proferentem (literally 'against the proffering person') but specific treatment varies between jurisdictions.

United States 


\section{Generally}

The Uniform Commercial Code which is followed in most American states has specific provisions relating to standard form contracts. Furthermore, standard form contracts will be subject to special scrutiny if they are found to be contracts of adhesion.

\section{Contracts of adhesion}

The concept of the contract of adhesion originated in French civil law, but did not enter American jurisprudence until the Harvard Law Review published an influential article by Edwin W. Patterson in 1919. It was subsequently adopted by the majority of American courts, especially after the Supreme Court of California endorsed adhesion analysis in 1962. See Steven v. Fidelity \& Casualty Co., 58 Cal. 2d 862, 882 n.10 (1962) (reciting history of concept) [3].

For a contract to be treated as a contract of adhesion, it must be presented on a standard form on a 'take it or leave it' basis, and give the purchaser no ability to negotiate because of their unequal bargaining position. The special scrutiny given to contracts of adhesion can be performed in a number of ways:

- If the term was outside of the reasonable expectations of the person who did not write the contract, and if the parties were contracting on an unequal basis, then it will not be enforceable. The reasonable expectation is assessed objectively, looking at the prominence of the term, the purpose of the term and the circumstances surrounding acceptance of the contract.

- Section 211 of the American Law Institute's Restatement (Second) of Contracts, which has persuasive though non-binding force in courts, provides:

Where the other party has reason to believe that the party manifesting such assent would not do so if he knew that the writing contained a particular term, the term is not part of the agreement.

This is a subjective test focusing on the mind of the seller and has been adopted by only a few state courts.

- The doctrine of unconscionability which is a fact-specific doctrine arising from equitable principles. Unconscionability in standard form contracts usually arises where there is an "absence of meaningful choice on the part of one party due to one-sided contract provisions, together with terms which are so oppressive that no reasonable person would make them and no fair and honest person would accept them." (Fanning v. Fritz's Pontiac-Cadillac-Buick Inc.) 


\section{Shrink wrap contracts}

Courts in the United States have faced the issue of shrink wrap contracts in two ways. One line of cases follows ProCD v. Zeidenberg which held such contracts enforceable (eg. Brower v Gateway [4]) and the other follows Klocek v. Gateway, Inc which found them unenforceable (eg. Specht v. Netscape Communications Corp. [5]). These decisions are split on the question of consent, with the former holding that only objective manifestation of consent is required while the latter require at least the possibility of subjective consent.

Canada

In Canada, exemption clauses in a standard form contract must be brought to the attention of the purchaser for them to have effect (Tilden Rent-A-Car Co. v. Clendenning).

Australia

Standard form contracts have generally received little special treatment under Australian common law. A 2003 New South Wales Court of Appeal case (Toll (FGCT) Pty Limited v Alphapharm Pty Limited) gave some support for the position that notice of exceptional terms is required for them to be incorporated. However the defendant successfully appealed to the High Court so currently there is no special treatment of standard form contracts in Australia.

\section{Legislation}

In recognition of the consumer protection issues which may arise, many governments have passed specific laws relating to standard form contracts. These are generally enacted on a state level as part of general consumer protection legislation and typically allow consumers to avoid clauses which are found to be unreasonable, though the specific provisions vary greatly. Some laws require notice to be given for these clauses to be effective, others prohibit unfair clauses altogether (eg. Victorian Fair Trading Act 1999).

Integration clause

In the contract law, an integration clause (sometimes, particularly in the United Kingdom, referred to an entire agreement clause) is a term in the language of the contract that declares it to be the complete and final agreement between the parties. The existence of such a term is conclusive proof that no varied or additional conditions exist with respect to the performance of the contract beyond those that are in the writing. A contract that has such a clause is deemed 
an integrated contract, and any previous negotiations in which the parties to the contract had considered different terms will be deemed superseded by the final writing. Sometimes is also known as "Entire Agreement" Clause, and, in its case, it is usually drafted at the end of the contract.

Sample clause

"This Agreement (and any documents referred to in it) contains the whole agreement between the Parties relating to the transactions contemplated by this Agreement and supersedes all previous understandings and agreements between the Parties relating to these transactions. Each Party acknowledges that, in agreeing to enter into this Agreement, it has not relied on any representation, warranty, collateral contract or other assurance (except those set out in this Agreement and any documents referred to in it) made by or on behalf of any other Party or any other person whatsoever before the execution of this Agreement. Each Party waives all rights and remedies which, but for this Clause, might otherwise be available to it in respect of any such representation, warranty, collateral contract or other assurance, provided that nothing in this Clause shall limit or exclude any liability for willful misconduct or fraud."

Contra proferentem

Construction contra proferentem is the rule of contract interpretation that where a provision's meaning is ambiguous, it should be read against the party who wrote it. That is, the preferred interpretation will be the one that helps the party who drafted it the least.

The reasoning behind this rule is to encourage the drafter of a contract to be as clear and explicit as possible and to take into account as many foreseeable situations as he can.

Additionally, the rule reflects the court's inherent dislike of standard-form takeit-or-leave-it contracts (e.g., standard form agreements all club members must sign). The court perceives such contracts as displaying an unfair or uneven bargaining position. To compensate for this, the court applies contra proferentem to take a strict approach and at times, striking down the terms to the favour of the other party.

Contra proferentem also places the cost of losses on the party who was in the best position to avoid the harm. This is generally the person who drafted the contract. An example of this is the insurance contract, a great example of the 
contract of adhesion, above. There, the insurance company is the party that is completely in control of the terms of the contract and is generally in a better position to, for example, avoid contractual forfeiture. This is a principle of long standing. See, for example, California Civil Code $\$ 1654$ (“'In cases of uncertainty ... the language of a contract should be interpreted most strongly against the party who caused the uncertainty to exist." California enacted this section in 1872. Numerous other states have codified the rule as well.

As of today, 2006, international legislation such as the European Principles of Contract Law, have also codified this rule of law. Also, in arbitration procedure of the ICC (International Chamber of Commerce) there are (few) cases in which arbitrators recall the principle of contra proferentem in their legal reasoning. Last but not least, this principle has also been used by teams of many different universities of many different countries, when they met in Vienna in 2006 for the Willem C Vis International Commercial Arbitration Moot (e.g. Chapter 1 of the Claimant Memorandum of the RuG University, NL).

The term is frequently mis-spelled "contra proferentum". The derivation is the Latin contra (against) proferentem (the one bringing forth).

Excuses for non-performance

Mistake

In contract law a mistake is incorrect understanding by one or more parties to a contract and may be used as grounds to invalidate the agreement. Common law has identified three different types of mistake in contract: unilateral mistake, mutual mistake, and common mistake.

Unilateral mistake

A unilateral mistake is where only one party to a contract is mistaken as to the terms or subject-matter. The courts will uphold such a contract unless it was determined that the non-mistaken party was aware of the mistake and tried to take advantage of the mistake.

Leading cases on unilateral mistake are Smith v. Hughes [1871] and Hartog v. Colin \& Shields [1939] 3 All E.R. 566.

Mistake of identity

It is also possible for a contract to be void if there was a mistake in the identity of the contracting party. In the leading English case of Lewis v Avery [1971] 3 All ER 907 Lord Denning held that the contract can be avoided only if the plaintiff 
can show, that at the time of agreement, the plaintiff believed the other party's identity was of vital importance. A mere mistaken belief as to the credibility of the other party is not sufficient.

\section{Mutual mistake}

A mutual mistake is when both parties of a contract are mistaken as to the terms. Each believes they are contracting to something different. The court usually tries to uphold such a mistake if a reasonable interpretation of the terms can be found. However Mistake as to Identity, Shogun Finance v Hudson (2004) is now the leading case on mistake as to identity. In this case the House of Lords stated there was a strong presumption the owner intends to contract with the person physically present before him and only in extreme cases would the presumption be rebutted.

The famous case of the Peerless ship is an example in the case of Raffles $v$. Wichelhaus, (1864) 2 Hurl. \& C. 906. The defendant had made an order for the purchase of cotton for goods arriving on a certain boat Peerless from Bombay leaving in October. However a different boat arrived called Peerless, also from Bombay, but having left in December. The plaintiff merchant sought to enforce the contract for the sale of cotton, but the defendant refused stating that it was not the cotton that he had ordered. The court stated that reasonable meaning must be found. However, on the facts, there was no single reasonable interpretation of the terms, both parties were equally mistaken, thus the contract was void.

Shogun Finance $v$ Hudson (2004) is now the leading case on mistake as to identity. In this case, the House of Lords stated there was a strong presumption the owner intends to contract with the person physically present before him and only in extreme cases would the presumption be rebutted.

Common mistake

A common mistake is where both parties hold the same mistaken belief of the facts.

The House of Lords case of Bell v. Lever Brothers Ltd. established that common mistake can void a contract only if the mistake of the subject-matter was sufficiently fundamental to render its identity different from what was contracted, making the performance of the contract impossible. 
Later in Solle v. Butcher, Lord Denning added requirements for common mistake in equity, which loosened the requirements to show common mistake. However, since that time, the case has been heavily criticized in cases such as Great Peace.

Misrepresentation

In contract law, a misrepresentation is a false statement of fact made by one party to another party and has the effect of inducing that party into the contract. For example, under certain circumstances, false statements or promises made by a seller of goods regarding the quality or nature of the product that the seller has may constitute misrepresentation. A finding of misrepresentation allows for a remedy of rescission and sometimes damages depending on the type of misrepresentation.

According to Gordon v Selico (1986) 18 HLR 219 it is possible to make a misrepresentation either by words or by conduct, although not everything said or done is capable of constituting a misrepresentation. Generally, statements of opinion or intention are not statements of fact in the context of misrepresentation. If one party claims specialist knowledge on the topic discussed, then it is more likely for the courts to hold a statement of opinion by that party as a statement of fact.

Representation is not a term

To seek a remedy under misrepresentation it must first be determined that the representation is not a term of the contract (i.e. a warranty or condition). This is determined objectively by the trier of fact by looking at the time that the representation was made: the closer to the moment of contract formation, the more likely it is a term. If there is any mention of the representation in writing, then it could be construed as part of the contract.

As well, the Courts will often attempt to find a collateral contract by interpreting the representation as a promise accompanied by some sort of consideration (see Heilbut, Symons \& Co. v. Buckleton [1913] A.C. 30 (H.L.)). The collateral contract will have the effect of adding the representation as a term to the contract.

If the representation is found to be a term then the normal remedies for breach of contract apply.

Types of misrepresentation 
There are three types of misrepresentation. Depending on the type, the remedies available vary:

- $\quad$ Fraudulent misrepresentation (Derry $\mathbf{v}$ Peek) is when the representation is made with intent to deceive and with the knowledge that it is false. This is generally a difficult type of misrepresentation to prove but allows for a remedy of both damages and rescission. An action for fraudulent misrepresentation can also be brought as a tort. Fraudulent misrepresentation is capable of being made recklessly.[3]

- Negligent misrepresentation at common law is when the representation is made carelessly while having no reasonable reasons for believing it to be true. This class of misrepresentation is relatively new and was introduced in order to allow for a remedy of damages in situations where neither a collateral contract nor fraud could be found. It was first seen in the case of Hedley Byrne v. Heller [1964] A.C. 465 where the court found that a statement made negligently that was relied upon can be actionable in tort. Lord Denning in Esso Petroleum Co. Ltd. v. Mardon [1976] Q.B. 108 however, transported the tort into contract law, stating the rule as:

if a man, who has or professes to have special knowledge or skill, makes a representation by virtue thereof to another... with the intention of inducing him to enter into a contract with him, he is under a duty to use reasonable care to see that the representation is correct, and that the advice, information or opinion is reliable There is also negligent misrepresentation in Statute, with the introduction of the Misrepresention Act 1967, when dealing with a negligent misrep it is better for an action to be brought under statute law as the burden of proof that is required passes to the person who made the statement. So it is for the person who made the negligent statement to prove that the statement was either not one of fact but opinion and that they truly believed the statement to be true at the time of making it.

- Innocent misrepresentation is when the representor had reasonable grounds for believing that his or her false statement was true. Proir to the Hedley Burn v Heller \& Partners [1964] all misrepresentations that were not fraudulent were considered to be innocent. This type of representation only allows for a remedy of rescission. The purpose of which is put the parties back into a position as if the contract had never taken place. 


\section{Remedies}

\section{Rescission}

Generally, the effect of misrepresentation is that it makes the contract voidable (the representee can choose whether to affirm the contract or have it rescinded). Rescission can be done either by informing the representor or by requesting an order from the court. There are certain circumstances where rescission is not possible though. The idea behind rescission is that the parties are restored to the positions they were before entering into the contract. Therefore, if this is not possible, rescission is not an option.[4]

If the representee discovers the misrepresentation and fails to take steps to avoid the contract, then he may not be able to rescind It. [5] the time limit for taking such steps varies depending on the type of misrepresentation. In cases of fraudulent misrepresentation, the time limit runs until when the misrepresentation ought to have been discovered, whereas in innocent misrepresentation, the right to rescission may lapse even before the representee can reasonably be expected to know about it. [6]

In certain circumstances, third party rights may interfere with rescission and render it impossible. For example, if $B$ contracts with $A$ to sell a house with a misrepresentation and then a sells the house to $\mathrm{C}$, the courts are not likely to permit rescission as that would require $\mathrm{C}$ to give up the house.

In England and Wales, under s. 2(2) of the Misrepresentation Act 1967, the court has the discretion to award damages instead of rescission.

\section{Damages}

In cases of fraudulent misrepresentation, a claim for damages is under the tort of deceit, making the damages tortuous, in other words, only actual losses are recoverable. If the losses are calculated under the Misrepresentation Act 1967, damages for misrepresentation are calculated as if the defendant had been fraudulent, even if he has been only negligent. This is a wider scope than usual tortious liability, as it protects the claimant's loss even if it was not reasonably foreseeable. Inclusion of the representation into the contract as a condition will leave the remedy for breach in damages as a common law right. The difference is that damages for misrepresentation usually reflect $C^{\prime}$ 's reliance interest, whereas damages for breach of contract protect C's expectation interest, although the rules on mitigation will apply in this case. In certain cases though, the courts 
have awarded damages for loss of profit, basing it on loss of opportunity.[7] In cases of negligent misrepresentation, a claim for damages may be made either in the tort of negligence or under s. 2(1) of the Misrepresentation Act 1967 (England and Wales).

In cases of innocent misrepresentation, the court has discretion to award damages instead of rescission. Such damages are intended to accomplish the same thing as rescission: restoration of the parties to their original positions, rather than compensate any losses. The result of this is that damages for any losses other than what was agreed to be transferred are not recoverable. Frustration of purpose

Frustration of purpose is a term used in the law of contract to describe a defense to an action for non-performance based on the occurrence of an unforeseen event which makes performance impossible, illegal or radically different from what was originally intended. A common situation is that the subject matter of the contract - a house or a car for example - is unintentionally destroyed.

Generally, the non-performance is not excused. If the seller retained the risk of loss from damage or destruction, then the non-performance will likely be excused. However, if it is the buyer who carries the risk of loss, performance will not be excused. A seller will not be excused for nonperformance of an agreement to deliver a commodity. For example, if A agrees to sell B 100 bushels of corn, and A's own crops are destroyed in an accident, $A$ is still contractually obliged to sell B 100 bushels of corn because A can still obtain the corn elsewhere for the sale.

Frustration of purpose also arises as a defense where one party to the contract dies, if that party was uniquely necessary to the performance of the contract. Passage of a subsequent law that makes performance illegal will also excuse nonperformance under this doctrine.

The leading case in English law on the subject is the famous 1903 case of Krell $v$. Henry, which concerned a party who had rented a room for the purpose of watching the coronation procession of Edward VII.

Frustration of purpose is distinguishable from the doctrine of impossibility/impracticability in that frustration of purpose is typically used by the buyer and Impossibility is used by the seller.

Impossibility 
"Doctrine of Impossibility" is an excuse for non-performance of duties under a contract, based on a change in circumstances (or the discovery of preexisting circumstances), the nonoccurrence of which was an underlying assumption of the contract that makes performance of the contract literally impossible. For such a defense to be raised performance must not merely be difficult or unexpectedly costly for one party; there must be no way for it to actually be accomplished.

For example, if Rachel contracts to pay Joey $£ 500$ to paint her house on October 1 , but the house burns to the ground before the end of September, Rachel is

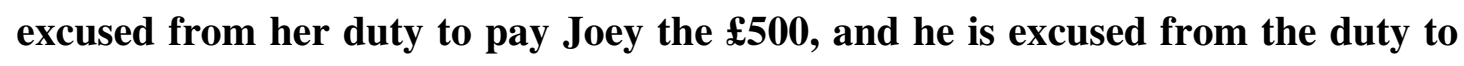
paint her house. However, Joey still may be able to sue for restitution for the benefit conferred to Rachel prior to the burning down of the house.

The English case which established this doctrine at common law is Taylor v. Caldwell.

\section{Unclean hands}

Unclean hands, sometimes clean hands doctrine, is an equitable defense in which the defendant argues that the plaintiff is not entitled to obtain an equitable remedy on account of the fact that the plaintiff is acting unethically or has acted in bad faith with respect to the subject of the complaint-that is with 'unclean hands'. The defendant has the burden of proof to show the plaintiff is not acting in good faith. The doctrine is often stated as "those seeking equity must do equity".

Equitable remedies are generally remedies other than the payment of damages. This would include such remedies as obtaining an injunction, or requiring specific performance of a contract. Before the development of the courts of equity in England, such remedies were unavailable in the common law courts. Such remedies were developed in the equity courts as the payment of damages was often not a sufficient remedy for a plaintiff in certain circumstances. For example, if a landowner polluted the land of the neighbour, the common law tort of nuisance would only allow the innocent party to recover damages. Common law had no remedy that would force the defendant to stop the pollution. Equity courts developed such a remedy, the injunction that provided an ongoing bar to the activity that caused the damage.

Equity courts realized that such extraordinary remedies were only justified in extraordinary cases, and would generally not grant such a remedy where 
damages were sufficient to make the plaintiff whole. For example, if a car dealership broke a contract of sale and refused to deliver a particular car, which now could only be obtained for $\$ 10,000$ more than what the plaintiff was willing to pay, the courts would merely award the plaintiff $\$ 10,000$ (in addition to the original amount paid, if it had already been paid). It would not force the dealer to obtain the exact same car and sell it to the plaintiff. However, if the subject matter of the sale were a particular work of art, the court would order specific performance and require the sale of the art work.

However, equity courts also realized that these extraordinary remedies were subject to abuse. For example, if a doctor had signed a non-compete agreement with a clinic, the non-compete clause might prevent the doctor from earning a living if he left the clinic's employment. As such, the court will generally only grant these remedies on the strictest terms. If there is any indication that the plaintiff seeking the remedy had acted in bad faith, either prior to the commencement of the litigation or afterwards, the court will generally not grant the remedy. For example, if the doctor left the clinic because it was involved in insurance fraud, a court would most likely refuse to enforce the noncompete agreement by issuing an injunction, although it might allow the clinic to recover damages if they did lose business to the doctor.

A defendant's unclean hands can also be claimed and proven by the plaintiff to prevent that defendant from asserting equitable affirmative defenses and claiming other equitable remedies. In other words, 'unclean hands' can be used offensively by the plaintiff as well as defensively by the defendant. Historically, the doctrine of unclean hands can be traced as far back as the Fourth Lateran Council.

\section{Unconscionability}

Unconscionability (also known as Unconscientious Dealings) is a term used in contract law to describe a defense against the enforcement of a contract based on the presence of terms unfair to one party. Typically, such a contract is held to be unenforceable because the consideration offered is lacking or is so obviously inadequate that to enforce the contract would be unfair to the party seeking to escape the contract.

In and of itself, inadequate consideration is likely not enough to make a contract unenforceable. However, a court of law will consider evidence that one party to 
the contract took advantage of its superior bargaining power to insert provisions that make the agreement overwhelmingly favor the interests of that party. Usually for a court to find a contract unconscionable the party claiming unconscionability will have to prove both that there was a problem with the substance of the contract and the process through which that contract was formed. The substantive problem will usually be the consideration, but could also be the terms, interest payments, or other obligations the court finds unfair. Procedural issues that a court could consider include a party's lack of choice, superior bargaining position or knowledge, and other circumstances surrounding the bargaining process.

Upon finding unconscionability a court has a great deal of flexibility on how it remedies the situation. It may refuse to enforce the contract, refuse to enforce the offending clause, or take other measures it deems necessary to have a fair outcome. Damages are usually not awarded.

Typical scenarios

There are several typical scenarios in which unconscionability is most frequently found:

1. Where a party that typically engages in sophisticated business transactions inserts boilerplate language into a contract containing terms unlikely to be understood or appreciated by the average person. Such terms might include a disclaimer of warranties, or a provision extending liability for a newly purchased item to goods previously purchased from the same seller.

2. Where a seller offers a contract of adhesion for the purchase of necessary goods (e.g. food, shelter, means of transportation).

3. Where a seller is vastly inflating the price of goods, particularly where this inflation is conducted in a way that conceals from the buyer the total cost for which the buyer will be liable.

For the defense of unconscionability to apply, the contract has to have been unconscionable at the time that it was made - later circumstances that have the effect of making the contract extremely one-sided are irrelevant. An interesting aspect of unconscionability is that the determination is made by the judge, not by a jury, despite the fact that such a determination is very fact-intensive. Unconscionability is only prevalent in terms of special disadvatage to the disabled. 
Case law

English case law

The leading case on this point is considered to be the English case of Lloyd's Bank v. Bundy. In that case, Bundy had agreed to increase the mortgage on his house in order to maintain the credit line being extended to his son's business. The English Court of Appeal ruled that as Bundy received no direct benefit from the agreement to increase the mortgage amount, and that the bank had threatened to call in the son's loan if Bundy had not agreed to the extension, and that the amount of the loan was already higher than the existing mortgage, that the transaction was unconscionable and Bundy only had to honor the lower mortgage. Essentially, the court ruled that only the bank benefited from the agreement to raise the amount of the mortgage.

Canadian case law

In the case of Harry v. Kreutziger, a member of the First Nations was allowed to rescind a contract for the sale of his boat and fishing license for a nominal amount. The boat was worthless but, unknown to the native, his fishing license was worth a great deal of money, and could have been mortgaged to finance a new boat. The court ruled that the buyer was merely trying to take advantage of the seller's lack of knowledge of the value of the license and refused to allow the contract to be enforced.

However, sorely inadequate consideration in and of itself is not a determination of whether a transaction is unconscionable. For example, in an Ontario case, a property owner agreed to sell an option for the sale of his property for the sum of \$1.00. The owner later learned that options to purchase property usually sell for more than nominal sums. The court enforced the contract in favor of the option holder, ruling that the negotiations over the price of the option and the price the option holder would pay for the house if he chose to buy were both fairly negotiated and that the seller had adequate opportunity to investigate the market and simply did not do so.

Australian case law

The leading Australian case is Commercial Bank of Australia Ltd v. Amadio (1983) 151 CLR 447. In this case, an elderly Italian couple with little command of English secured their son's debts arising from his failing business. Their son misled them as to the extent of the guarantee, and the bank did nothing to 
explain it to the parents. When the son's business failed, the Amadios had the contract set aside due to unconscionable dealing by the bank. Key elements that were relied upon were:

1. the parties must meet on unequal terms, such that one party has a disability Vis a Vis the other party, through such things as infirmity, age and language.

2. the stronger party knows of the special disability, or should have been aware of the special disability, and takes advantage of it.

3. The stronger party obtains a bargain which would be unconscionable to retain.

Illegal agreement

An illegal agreement, under the common law of contract, is one that the courts will not enforce because the purpose of the agreement is to achieve an illegal end. The illegal end must result from performance of the contract itself, however. A contract that requires only legal performance, such as the sale of packs of cards to a known gambler, where gambling is illegal, will nonetheless be enforceable. A contract to pay a gambling debt, however, will not.

A famous example in the United States is Bovard v. American Horse Enterprises 247 Cal. Rptr. 340 (1988), in which the California Supreme Court refused to enforce a contract for payment of promisory notes used for the purchase of a company that manufactured drug paraphernalia.

In Canada, one cited case of lack of enforceability based on illegality is Royal Bank of Canada v. Newell, 147 D.L.R (4th) 268 (N.C.S.A.), in which a woman forged her husband's signature on 40 cheques, totalling over $\$ 58,000$. To protect her from prosecution, her husband signed a letter of intent prepared by the bank in which he agreed to assume "all liability and responsibility" for the forged cheques. However, the agreement was unenforceable, and struck down by the courts, because of its essential goal, which was to "stifle a criminal prosecution." Because of the contract's illegality, and as a result voided status, the bank was forced to return the payments made by the husband.

Contracts in restraint of trade are a variety of illegal contracts and generally will not be enforced unless they are reasonable in the interests of the contracting parties and the public.

Accord and satisfaction 
Accord and satisfaction is the purchase of the release from a debt obligation. The payment is typically less than what is owed and is not paid by the actual performance of the original obligation. The accord is the agreement to discharge the obligation and the satisfaction is the legal "consideration" which binds the parties to the agreement.

If a person is sued over an alleged debt they bear the burden of proving the affirmative defense of accord and satisfaction.

- Foakes v. Beer - an old leading case on the exception of accord and satisfaction

- $\quad$ Part performance - related legal concept

Accord and satisfaction is a settlement of an unliquidated debt. For example, a builder is contracted to build a homeowner a garage for $\$ 35,000$. The contract called for $\$ 17,500$ prior to starting construction, to disburse $\$ 10,000$ during various stages of construction, and to make a final payment of $\$ 7,500$ at completion. At completion, the homeowner complained about inferior work quality and refused to make the final payment. After a mutual settlement agreement, the builder accepted $\$ 4,000$ as full payment. Thereby, new contract was formed by offer, acceptance, and consideration. The consideration is that for a \$3,500 savings, the homeowner gives up that which he is entitled, a wellconstructed garage. The builder gives up his right to full price to avoid suit for inferior performance. When accord and settlement has occurred, the homeowner and builder have given up his right to sue for more money under this settlement agreement.

Rights of third parties

The doctrine of privity in contract law provides that a contract cannot confer rights or impose obligations arising under it on any person or agent except the parties to it.

This seems to make adequate sense, in that only parties to contracts should be able to sue to enforce their rights or claim damages as such. However the doctrine has proven problematic due to its implications upon contracts made for the benefit of third parties who are unable to enforce the obligations of the contracting parties.

Assignment 
An assignment is a term used with similar meanings in the law of contracts and in the law of real estate. In both instances, it encompasses the transfer of rights held by one party - the assignor - to another party - the assignee. The legal nature of the assignment determines some additional rights and liabilities that accompany the act.

\section{Liabilities}

Continuing Liability of Assignor

Assignor remains liable unless there is an agreement to the contrary.

Liability of Assignee: generally not liable

Consumer Protection, Defenses and Setoffs

Warranties of Assignor

Assignment of contract rights

Assignment of rights under a contract is the complete transfer of the rights to receive the benefits accruing to one of the parties to that contract. For example, if party contracts with Party $B$ to sell his car to him for $\$ \mathbf{1 0}$, party a can later assign the benefits of the contract - the right to be paid $\$ 10$ - to party $C$. In this scenario, party $A$ is the obligee/assignor, party $B$ is an obligor, and party $C$ is the assignee. Such an assignment may be donative (essentially given as a gift), or it may be contractually exchanged for consideration. It is important to note, however, that party $C$ is not a third party beneficiary, because the contract itself was not made for the purpose of benefitting party C. However an Assignment only transfers the rights/benefits to a new owner. The obligations remain with the previous owner. Compare Novation.

When assignment will be permitted

The common law favors the freedom of assignment, so an assignment will generally be permitted unless there is an express prohibition against assignment in the contract. Where assignment is thus permitted, the assignor need not consult the other party to the contract. An assignment cannot have any effect on the duties of the other party to the contract, nor can it reduce the possibility of the other party receiving full performance of the same quality. Certain kinds of performance, therefore, cannot be assigned, because they create a unique relationship between the parties to the contract. For example, if party A contracts to hire an attorney to represent her in a civil case for a fee of $\$ 1000$, she cannot then assign her contractual right to legal representation to another party. 
Note however, that party A can assign her right to sue under the same claim she contracted with the attorney to pursue.

Requirements for an effective assignment

For assignment to be effective, it must occur in the present. No specific language is required to make such an assignment, but the assignor must make some clear statement of intent to assign clearly identified contractual rights to the assignee. A promise to assign in the future has no legal effect. Although this prevents a party from assigning the benefits of a contract that has not yet been made, a court of equity may enforce such an assignment where an established economic relationship between the assignor and the assignee raised an expectation that the assignee would indeed form the appropriate contract in the future.

A contract may contain a non-assignment clause, which prohibits the assignment of specific rights, or of the entire contract, to another. However, such a clause does not necessarily destroy the power of either party to make an assignement. Instead, it merely gives the other party the ability to sue for breach of contract if such an assignment is made. However, an assignment of a contract containing such a clause will be ineffective if the assignee knows of the non-assignment clause, or if the non-assignment clause specifies that "all assignments are void". Two other techniques to prevent the assignment of contracts are recission clauses or clauses creating a condition subsequent. The former would give the other party to the contract the power to rescind the contract if an assignment is made; the latter would rescind the contract automatically in such circumstances.

Requirement of writing

There are certain situations in which the assignment must be in writing.

1. Assignment of wages

2. Assignment of any interest in real property

3. Assignment of choses of action worth over $\$ 5,000$

4. Assignment as collateral for a loan or debt

For more information about contractual writing requirements see Statute of frauds.

Revocability

Assignments made for consideration are irrevocable, meaning that the assignor permanently gives up the legal right to take back the assignment once it has been made. Donative assignments, on the other hand, are generally revokable, either 
by the assignor giving notice to the assignee, taking performance directly from the obligor, or making a subsequent assignment of the same right to another. There are some exceptions to the revocability of a donative assignment:

1. The assignment can not be revoked if the obligor has already performed

2. The assignment can not be revoked if the assignee has received a token chose (chose being derived from the French word for "thing", as in a chose of action) - a physical object that signifies a right to collect, such as a stock certificate or the passbook to a savings account.

3. The assignment can not be revoked if the assignor has set forth in writing the assignment of a simple chose - a contract right not embodied in any for of token.

4. Estoppel can prevent the revocation of a donative assignment if the asignee changed their position in reliance on the assignment.

Finally, the death or declaration of bankruptcy by the assignor will automatically revoke the assignment by operation of law.

Breach and defenses

A cause of action for breach on the part of the obligor lie with the assignee, who will hold the exclusive right to commence a cause of action for any failure to perform or defective performance. At this stage, because the assignee "stands in the shoes" of the assignor, the obligor can raise any defense to the contract that the obligor could have raised against the assignor. Furthermore, the obligor can rise against the assignee counterclaims and setoffs that the obligor had against the assignor. For example, suppose that A makes a contract to paint B's house in exchange for $\$ 500$. A then assigns the right to receive the $\$ 500$ to $\mathrm{C}$, to pay off a debt owed to $C$. However, A does such a careless job painting the house that $B$ has to pay another painter $\$ 400$ to correct $A$ 's work. If $C$ sues $B$ to collect the debt, B can raise his counterclaim for the expenses caused by the poor paint job, and can reduce the amount owed to $C$ by that $\$ 400$, leaving only $\$ 100$ to be collected.

When the assignor makes the assignment, he makes with it an implied warranty that the right to assign was not subject to defenses. If the contract had a provision that made the assignment ineffective, the assignee could sue the assignor for breach of this implied warranty. Similarly, the assignee could also sue under this theory if the assignor wrongfully revoked the assignment. 


\section{Successive assignments}

Occasionally, an unscrupulous assignor will assign the exact same rights to multiple parties (usually for some consideration). In that case, the rights of the assignee depend on the revocability of the assignment, and on the timing of the assignments relative to certain other actions.

In a quirk left over from the common law, if the assigment was donative, the last assignee is the true owner of the rights. However, if the assignment was for consideration, the first assignee to actually collect against the assigned contract is the true owner of the rights. Under the modern American rule, now followed in most U.S. jurisdictions, the first assignor with equity (i.e. the first to have paid for the assignment) will have the strongest claim, while remaining assignees may have other remedies. In some countries, the rights of the respective assignees are determined by the old common law rule in Dearle v Hall.

1. Earlier donative assignees for which the assignment was revocable (because it had not been made irrevocable by any of the means listed above) have no cause of action whatsoever.

2. Earlier donative assignees for which the assignment was made irrevocable can bring an action for the tort of conversion, because the assignment was technically their property when it was given to a later assignee.

3. Later assignees for consideration have a cause of action for breaches of the implied warranty discussed above.

\section{Compare: Delegation}

A parallel concept to assignment is delegation, which occurs when one party transfers his duties or liabilities under a contract to another. A delegation and an assignment can be accomplished at the same time, although a non-assignment clause also bars delegation.

Real property rights can be assigned just as any other contractual right. However, special duties and liabilities attach to transfers of the right to possess property. With an assignment, the assignor transfers the complete remainder of the interest to the assignee. The assignor must not retain any sort of reversionary interest in the right to possess. The assignee's interest must abut the interest of the next person to have the right to possession. If any time or interest is reserved by a tenant assignor, than the act is not an assignment, but instead is a sublease. 
The liability of the assignee depends upon the contract formed when the assignment takes place. However, in general, the assignee has privity of estate with a lessor. With privity of estate comes the duty on the part of the assignee to perform certain obligations under covenant, e.g. pay rent. Similarly, the lessor retains the obligations to perform on covenants to maintain or repair the land.

If the assignor agrees to continue paying rent to the lessor and subsequently defaults, the lessor can sue both the assignor under the original contract signed with the lessor as well as the assignee because by taking possession of the property interest, the assignee has obliged himself to perform duties under covenant such as the payment of rent.

Assignment of partnership rights

A person can also assign their rights to receive the benefits owed to a partner in a partnership. However, the assignee can not thereby gain any of the assignor's rights with respect to the operation of the partnership. The assignee may not vote on partnership matters, inspect the partnership books, or take possession of partnership property; rather, the assignee can only be given the right to collect distributions of income. If the partnership is dissolved, the assignee can also claim the assignor's share of any distribution accompanying the dissolution.

Assignment of patent ownership

In the United States, assignment of a patent is governed by statute, 35 U.S.C. $§$ 261. Assignment of an interest occurs only by an "instrument in writing". The statute also permits recording an assignment with the United States Patent and Trademark Office, but recording is not required. See also transfer (patent)

Delegation

Delegation is a term used in the law of contracts to describe the act of giving another person the responsibility of carrying out the performance agreed to in a contract. Three parties are concerned with this act - the party who had incurred the obligation to perform under the contract is called the delegator; the party who assumes the responsibility of performing this duty is called the delegatee; and the party to whom this performance is owed is called the obligee.

Delegable contracts

A delegation will be null and void if it poses any threat to the commercially reasonable expectations of the obligee. For example, a task requiring specialized skills or based on the unique characteristics of the promisee can not be 
delegated. If George W. Bush were hired to make a speech, he could not delegate the task to another person, even if the other person would give the same speech, word for word.

However, a delegation of performance that does not pose such a threat will be held to be valid. In such a case, the obligee will under an affirmative duty to cooperate with the delegatee to the extent necessary for the fulfillment of the delegator's obligations under the contract.

Breach of a delegated contract

If the delegatee fails to perform satisfactorily, the obligee may elect to treat this failure as a breach of the original contract by the delegator or may assert himself as a third party beneficiary of the contract between the delegator and the delegatee, and can claim all remedies due to a third party beneficiary.

If the delegation is without consideration, the delegator remains liable for nonperformance, while the delegatee will not be liable to anyone for anything. Unlike an assignment, a delegation is virtually always for consideration, and never donative - few people are going to accept the charitable offer to perform a task contracted to someone else.

Compare: assignment

A parallel concept to delegation is assignment, which occurs when one party transfers his present rights to receive the benefits accruing to the assignor under that contract. A delegation and an assignment can be accomplished at the same time, although the right to sue for nonpayment always stays with delegator. Under the common law, a contract clause prohibiting assignment also prohibits delegation. Another common law rule requires that a party to a contract can not delegate performance that involves special skills or reputation (although it is possible to have a novation under such circumstances).poop

\section{Novation}

Novation is a term used in contract law and business law to describe the act of either replacing an obligation to perform with a new obligation, or replacing a party to an agreement with a new party. A novation need not be agreed upon by all the parties to the original agreement. The obligee, the person receiving the benefit of the bargain, must only is given notice. The obligor, the party making the novation, must only make the new obligor aware and receive consent from 
the new obligor. A contract transferred by the novation process transfers all duties and obligations from the original obligor to the new obligor.

A typical example of a novation is where a person has the rights to receive loans from a Bank (Bank A). Bank A can make a novation by asking Bank B if they will accept the duties and liabilities of providing loan payments to the person. If Bank B accepts this novation, (which they would typically do if they owed Bank a something) then the person receiving the loans does NOT have to consent. As a practical matter though, it would be wise to make them aware of this change.

Novation is also used in futures/options trading markets to describe a special situation where the clearing house takes all positions with all the brokers, buying all the brokers sell, and selling all that the brokers buy.

In business, novation is typically the process by which a newly formed corporation assumes the pre-incorporation liabilities incurred by its founders.

Third party beneficiary

A third party beneficiary, in the law of contracts, is a person who may have the right to sue on a contract, despite not having originally been a party to the contract. This right arises where the third party is the intended beneficiary of the contract, as opposed to an incidental beneficiary. It vests when the third party relies on or assents to the relationship, and gives the third party the right to sue either the promisor or the promisee of the contract, depending on the circumstances under which the relationship was created.

In English law, the doctrine was not recognised at common law, but a similar concept was introduced with the Contracts (Rights of Third Parties) Act 1999.

Intended vs. incidental beneficiary

In order for a third party beneficiary to have any rights under the contract, he must be an intended beneficiary, as opposed to an incidental beneficiary. The burden is on the third party to plead and prove that he was indeed an intended beneficiary.

\section{Incidental beneficiary}

An incidental beneficiary is a party who stands to benefit from the execution of the contract, although that was not the intent of either contracting party. For example, if party $A$ hires party $B$ to renovate party A's house, and insists that party $B$ use a particular house painter-party $C$-because that house painter has an excellent reputation, then the house painter is an incidental beneficiary. 
Neither party A nor party $B$ is entering into the contract with the particular intent to benefit party $C$. Party A simply wants his house properly renovated; party $B$ simply wants to be paid to do the renovation. If the contract is breached by either party in a way that results in party $\mathrm{C}$ never being hired for the job, party $C$ nonetheless has no rights to recover anything under the contract. Similarly, if party A were to promise to buy party B a Cadillac, and were to later go back on that promise, General Motors would have no grounds upon which to recover for the lost sale.

Intended beneficiary

The distinction that creates an intended beneficiary is that one party - called the promisee - makes an agreement to provide some consideration to a second party - called the promisor - in exchange for the promisor's agreement to provide some product, service, or support to the third party beneficiary named in the contract. The promisee must have an intention to benefit the third party - but this requirement has an unusual meaning under the law. Although there is a presumption that the promisor intends to promote the interests of the third party in this way, if party A contracts with party $B$ to have a thousand killer bees delivered to the home of Party A's worst enemy, party $C$, then $C$ is still considered to be the intended beneficiary of that contract.

There are two common situations in which the intended beneficiary relationship is created. One is the creditor beneficiary, which is created where party A owes some debt to party $\mathrm{C}$, and party $\mathrm{A}$ agrees to provide some consideration to party $B$ in exchange for party $B$ 's promise to pay party $C$ some part of the amount owed.

The other is the donee beneficiary, which is created where party $A$ wishes to make a gift to party $\mathrm{C}$, and party $A$ agrees to provide some consideration to party $B$ in exchange for party $B$ 's promise to pay party $C$ the amount of the gift. Under old common law principles, the donee beneficiary actually had a greater claim to the benefits this created; however, such distinctions have since been abolished.

Vesting of rights

Once the beneficiary's rights have vested, the original parties to the contract are both bound to perform the contract. Any effort by the promisor or the promisee to rescind or modify the contract at that point is void. Indeed, if the promisee 
changed his mind and offered to pay the promisor money not to perform, the third party could sue the promisee for tortious interference with the third party's contract rights.

There are three tests used to determine whether the third party beneficiary's rights have vested:

1. if the beneficiary knows of and has detrimentally relied on the rights created

2. if the beneficiary has expressly assented to the contract at the request of one of the parties

3. if the beneficiary files a lawsuit to enforce the contract

Breach and defenses

Where a contract for the benefit of a third party is breached by the nonperformance of the promisor, the beneficiary can sue the promisor for the breach just as any party to a contract can sue the other. Because the rights of the third party are defined by the contract created between the promisor and the promisee, the promisor may assert against the beneficiary any defenses to the contract that could be asserted against the promisee. These include all of the traditional basis by which the formation of a contract may be challenged: lack of capacity, lack of consideration, the Statute of Frauds, etc.; and all of the traditional bases by which non-performance on the contract may be excused: failure of consideration, impossibility, illegality, frustration of purpose, etc.

Because the promisor can assert any defenses that could be asserted against the promisee, the beneficiary also becomes liable for counterclaims on the contract that the promisor could establish against the promisee. This liability can never exceed the amount that the promisor owes under the contract. In other words, if the promisor is owed money by the promisee, any award to the third party for the promisor's failure to perform can be reduced by the amount thus owed. If the promisor is owed more than the value of the contract, the beneficiary's recovery will be reduced to nothing (but the third party can never be made to assume an actual debt).

A creditor beneficiary can sue both the promisor and the promisee, but the beneficiary cannot recover against both. If the suit is successful against one party to the contract, the other party will be dismissed. Because the creditor beneficiary is receiving the performance of the promisor in order to fulfill the 
promisee's debt, the failure of the promisor to perform means that the beneficiary can still sue the promisee to recover the preexisting debt. The failure of performance simply means that the debt has never been paid.

A donee beneficiary can not sue the promisee, because the promisee's act is gratuitous. Courts simply will not allow a party who has been promised a gift to sue to compel delivery of the gift. However, if the beneficiary has relied to his detriment on the promisee's assertion that the promisor would perform, the beneficiary may sue the promisee under a promissory estoppel theory.

Rights that accrue to the promisee

The promisee can also sue the promisor for failing to pay the third party beneficiary. Under the common law, such suits were barred, but courts have since determined that the promisee can sue for specific performance of the contract, provided that the beneficiary has not already sued the promisor. Furthermore, if the promisee was in debt to a creditor beneficiary, and the failure of the promisor to perform caused the promisee to be held liable for that debt, the promisee can sue to recover the amount of the debt.

Breach of contract

Anticipatory repudiation (anticipatory breach)

Anticipatory repudiation (or anticipatory breach) is a term in the law of contracts that describes a declaration by one party (the promising party) to a contract that they do not intend to live up to their obligations under the contract. Where such an event occurs, the other party (the performing party) to the contract is excused from having to fulfill their obligations. However, the repudiation can be retracted by the promising party so long as there has been no material change in the position of the performing party in the interim. A retraction of the repudiation restores the performer's obligation to perform on the contract.

If the repudiation occurs by the promising party making it impossible to fulfill their promise, then no act by the promising party can restore the performer's obligation to perform on the contract. For example, if a promises to give $B$ a unique sculpture in exchange for $B$ painting A's house, but a then sells the sculpture to $\mathrm{C}$ before $\mathrm{B}$ begins the job, this act by $\mathrm{A}$ constitutes an anticipatory repudiation which excuses $B$ from performing. Once the sculpture has left A's 
possession, there is no way that $\mathrm{A}$ can fulfill the promise to give the sculpture to B.

The question arises as to why any party would want to provide notice of anticipatory breach. The reason is that once the performing party is informed of the anticipatory breach, a duty is then created for the performing party to mitigate damages as a result of the breach.

Cover

Cover is a term used in the law of contracts to describe a remedy available to a merchant buyer who has received an anticipatory repudiation of a contract for the receipt of goods. Under the Uniform Commercial Code, the buyer is permitted (but not required) to find another source of the same type of goods. The buyer may then file a lawsuit against the breaching seller to recover the difference, if any, between the cost of the goods offered and the cost of the goods actually purchased.

The possibility of cover will prevent a party from being able to sue for specific performance, which is an equitable remedy that requires the buyer have no adequate remedy at law. If the buyer is able to buy elsewhere and sue for the difference, that provides an adequate remedy. This prohibition does not apply, however, to the sale of unique goods such as original works of art, collectibles, real estate, and exclusive rights.

Judge Richard Posner has suggested that that the availability of cover allows for efficient breach - that is, that it encourages the most efficient allocation of resources by allowing a seller to breach a contract to sell goods to one buyer when another, more lucrative opportunity comes along. The seller may thus be able to realize a sufficiently increased profit to make more money even after repaying the difference to the original buyer. Therefore, no value is lost in the transaction because the original buyer is in the same position he would have been but for the breach, and the seller is in a better position.

Exclusion clause

An exclusion clause is a term in a contract that seeks to restrict the rights of the parties to the contract. Exclusion clauses generally fall into one of these categories:

- True exclusion clause: The clause recognises a potential breach of the contract, and then excuses liability for the breach. Alternatively, the clause is 
constructed in such a way it only includes reasonable care to perform duties on one of the parties.

- Limitation clause: The clause places a limit on the amount that can be claimed for a breach of contract, regardless of the actual loss.

- Time limitation: The clause states that an action for a claim must be commenced within a certain period of time or the cause of action becomes extinguished.

Traditionally, the courts have sought to limit the operation of exclusion clauses. In addition to numerous common law rules limiting their operation, in England and Wales, the main statutory interventions are the Unfair Contract Terms Act 1977 and the Unfair Terms in Consumer Contracts Regulations 1999. The Unfair Contract Terms Act 1977 applies to all contracts, but the Unfair Terms in Consumer Contracts Regulations 1999, unlike the common law rules, do differentiate between contracts between businesses and contracts between business and consumer, so the law seems to explicitly recognize the greater possibility of exploitation of the consumer by businesses.

The courts have traditionally held that exclusion clauses only operate if they are actually part of the contract. There seem to be three methods of incorporation:

- Incorporation by signature: according to L'Estrange v Graucob [1934] 2 KB 394, if the clause is written on a document which has been signed by all parties, then it is part of the contract.

- Incorporation by notice: the general rule is that an exclusion clause will have been incorporated into the contract if the person relying on it took reasonable steps to draw it to the other parties' attention. Thornton v Shoe Lane Parking [1971] 2 WLR 585, seems to indicate that the wider the clause, the more the party relying on it will have had to have done to bring it to the other parties' attention.

- Incorporation by previous course of dealings: according to McCutcheon v David MacBrayne Ltd [1964] 1 WLR 125, terms (including exclusion clauses) may be incorporated into a contract if course of dealings between the parties were "regular and consistent". What this means usually depends on the facts; however, the courts have indicated that equality of bargaining power between the parties may be taken into account. 
For an exclusion clause to operate, it must cover the breach (assuming there actually is a breach of contract). If there is, then the type of liability arising is also important. Generally, there are two varieties of liability: strict liability (liability arising due to a state of affairs without the party at breach necessarily being at fault) and liability for negligence (liability arising due to fault).

The courts have a tendency of requiring the party relying on the clause to have drafted it properly so that it exempts them from the liability arising, and if any ambiguity is present, the courts usually interpret it strictly against the party relying on the clause.

As espoused in Darlington Future Ltd v. Delcon Australia Pty Ltd (1986) 161 CLR 500, the meaning of an exclusion clause is construed in its ordinary and natural meaning in the context. Although we construe the meaning much like any other ordinary clause in the contract, we need to examine the clause in light of the contract as a whole.

However, if after construing the contract in its ordinary and natural meaning, there is still ambiguity in the exclusion clause, the contra proferentem rule shall apply; that is to say, the clause is construed against the person trying to take advantage of the rule.

In terms of negligence, the courts have taken the approach that it is unlikely that someone would enter into a contract that allows the other party to evade fault based liability. As a result, if a party wishes exempt his liability for negligence, he must make sure that the other parties understand that. The decision in Canada SS Lines Ltd v. The King [1952] AC 192 held that:

- If the exclusion clauses mention "negligence" explicitly, then liability for negligence is excluded.

- If "negligence" is not mentioned, then liability for negligence is excluded only if the words used in the exclusion clause are wide enough to exclude liability for negligence. If there is any ambiguity, then the contra proferentem rule applies.

- If a claim on another basis can be made, then liability for negligence is not covered by the exclusion clause.

In Australia, the four corners rule has been adopted in preference over the idea of a fundamental breach (The Council of the City of Sydney v. West (1965) 114 CLR 481). The court will presume that parties to a contract will not exclude 
liability for losses arising from acts not authorized under the contract. However, if acts of negligence occur during authorized acts, then the exclusion clauses shall still apply.

If the contract is for the carriage of goods, if the path is deviated from what was agreed, any exclusion clauses no longer apply.

\section{Efficient breach}

Efficient breach refers to a breach of contract that the breaching party considers desirable even when the legal and economic ramifications of such a breach are considered.

The first statement of the theory of efficient breach appears to have been made in a law review article by Robert Birmingham, Breach of Contract, Damage Measures, and Economic Efficiency, 24 Rutgers L.Rev. 273, 284 (1970) ("Repudiation of obligations should be encouraged where the promisor is able to profit from his default after placing his promisee in as good a position as he would have occupied had performance been rendered"). The theory was named by Charles Goetz and Robert Scott, Liquidated Damages, Penalties, and the Just Compensation Principle: A Theory of Efficient Breach, 77 Colum.L.Rev. 554 (1977).

Efficient Breach Theory is associated with Richard Posner and the Law and Economics school of thought. It has been used to defend the traditional common law rule that a non-tortious breach of contract cannot be remedied by punitive damages and penal damages (unreasonably excessive liquidated damages that are seen as a punishment for breach rather than a remedy). Such penalties would discourage efficient breach (therefore discouraging efficient behavior) and possibly put companies at increased risk of bankruptcy, which would be very bad for society. Posner explains his views in his majority opinion in Lake River Corp. v. Carborundum Co., 769 F.2d 1284 (7th Cir. 1985).

The theory of efficient breach is that such an action can result in an outcome that benefits the breaching party and society as a whole. To illustrate, suppose I contract to sell you a ton of bricks for $\$ 1,000$. We sign the contract, and then a third party comes along and offers me $\$ 1,500$ for that same ton (maybe he needs them more urgently). One might say that morally, I am obligated to sell you the bricks because I am bound by my promise. See, for example, Charles Fried's "Contract as Promise." Posner would say no -- I could choose to sell the other 
person the bricks. If you already paid me, I would have to refund you the $\$ 1,000$. If it costs you $\$ 1,100$ to get replacement bricks, and $\$ 100$ because of the delay in getting the replacement (e.g., your workers don't have bricks to use but you still have to pay their salaries), you would also be entitled to collect $\$ 200$ from me. This is known as the expectation interest because it puts you in as good a position as if I had performed the contract (if I had delivered the bricks when I said I would). Society is better off on net by at least $\$ 300$, because I am better off by $\$ 300$, whomever I sold the bricks to be better off, and no one is worse off.

Efficient breach is not a legal defense to a suit for breach of contract. If there is no defense, the breaching party must pay damages to the non-breaching party, such as the expectation interest described above.

Fundamental breach

Fundamental breach, sometimes known as a repudiatory breach, is a breach so fundamental that it permits the aggrieved party to terminate performance of the contract, in addition to entitling that party to sue for damages.

United Kingdom

In English law, fundamental breach was first examined by the House of Lords in the Suisse Atlantique case [1966] 2 All E.R. 61, wherein they decided that a contract can be voided if a breach of a fundamental term can be found. That is, a breach of a condition that "goes to the root of the contract". This approach is known as the Rule of Law doctrine.

At the Court of Appeal level in Photo Productions Ltd. v. Securicor Transport Ltd. [1978] 1 W.L.R. 856 Lord Denning championed the Rule of Law doctrine and extended the rule in Suisse Atlantique case to apply to all exemption clauses. However on appeal to the House of Lords Lord Wilberforce effectively overturned the Rule of Law doctrine and instead maintained a strict Rule of Construction approach whereby a fundamental breach is found only through examining the reasonable intentions of the parties at the time of the contract.

Canada

The leading case on fundamental breach in Canada is the case of Hunter Engineering Co. v. Integrated Metal Systems Ltd. [1989] 3 W.W.R. 385. In it they adopt similar reasoning as the House of Lords in Photo Productions, ruling that a fundamental breach is found through rule of construction only. 
The court should not disturb the bargain the parties have struck, and I am inclined to replace the doctrine of fundamental breach with a rule that holds the parties to the terms of their agreement, provided the agreement is not unconscionable ... Only where the contract is unconscionable, as might arise from situations of unequal bargaining power between the parties, should the courts interfere with agreements the parties have freely concluded.'

\section{Remedies}

\section{Specific performance}

In the law of remedies, an order of specific performance is an order of the court which requires a party to perform a specific act. While specific performance can be in the form of any type of forced action, it is usually used to complete a previously established transaction, thus being the most effective remedy in protecting the expectation interest of the innocent party to a contract. It is the opposite of an injunction.

Under the common law, specific performance was not a remedy, with the rights of a litigant being limited to the collection of damages. However, the courts of equity developed the remedy of specific performance as damages often could not adequately compensate someone for the inability to own a particular piece of real property, land being regarded as unique. Specific performance is often guaranteed through the remedy of a writ of possession, giving the plaintiff the right to take possession of the property in dispute. However, in the case of personal performance contracts, it may also be ensured through the threat of proceedings for contempt of court.

Orders of specific performance are granted when damages are not an adequate remedy, and in some specific cases such as land sale. Such orders are discretionary, as with all equitable remedies, so the availability of this remedy will depend on whether it is appropriate in the circumstances of the case.

There are certain circumstances where an order of specific performance would not be granted. Such circumstances include:

1. specific performance would cause severe hardship to the defendant

2. the contract was unconscionable

3. the claimant has misbehaved (no clean hands)

4. specific performance is impossible

5. performance consists of a personal service 


\section{6. the contract is too vague}

Additionally, in England and Wales, under s. 50 of the Supreme Court Act 1981, the High Court has a discretion to award a claimant damages in lieu of specific performance (or an injunction). Such damages will normally be assessed on the same basis as damages for breach of contract, namely to place the claimant in the position he would have been had the contract been carried out.

\section{Examples}

In practice, specific performance is most often used as a remedy in transactions regarding land, such as in the sale of land where the vendor refuses to convey title.

However, the limits of specific performance in other contexts are narrow. Moreover, performance that is based on the personal judgment or abilities of the party on which the demand is made is rarely ordered by the court. The reason behind it is that the forced party will often perform below the party's regular standard when it is in the party's ability to do so. Monetary damages are usually given instead.

Traditionally, equity would only grant specific performance with respect to contracts involving chattels where the goods were unique in character, such as art, heirlooms, and the like. The rationale behind this was that with goods being fungible, the aggrieved party had an adequate remedy in damages for the other party's non-performance.

In the United States, Article 2 of the Uniform Commercial Code displaces the traditional rule in an attempt to adjust the law of sales of goods to the realities of the modern commercial marketplace. If the goods are identified to the contract for sale and in the possession of the seller, a court may order that the goods be delivered over to the buyer upon payment of the price. This is termed replevin. In addition, the Code allows a court to order specific performance where "the goods are unique or in other proper circumstances", leaving the question of what circumstances are proper to be developed by case law.

In the civil law (the law of continental Europe and much of the non English speaking world) specific performance is considered to be the basic right. Money damages are a kind of "substitute specific performance." Indeed, it has been proposed that substitute specific performance better explains the common law rules of contract as well, see (Steven Smith, Contract Law, Clarenden Law ). 


\section{Liquidated damages}

Liquidated damages - damages are said to be liquidated (also referred to as liquidated and ascertained damages) when the amount of damages recoverable in the event of a specified breach (eg late performance) is agreed at the date of the contract. In such circumstances a liquidated damages provision will be included in the contract. When damages are not predetermined/assessed in advance then the amount recoverable is said to be 'at large' (to be agreed or determined by a court or tribunal in the event of breach).

At common law, a liquidated damages clause will not be enforced if its purpose is to punish the wrongdoer/party in breach rather than to compensate the injured party (in which case it is referred to as a penal or penalty clause). One reason for this, it could be said, is that the enforcement of the term would, in effect, require an equitable order of specific performance. However, courts sitting in equity will seek to achieve a fair result and will not enforce a term that will lead to the unjust enrichment of the enforcing party.

In order for a liquidated damages clause to be upheld, two conditions must be met. First, the amount of the damages identified must roughly approximate the damages likely to fall upon the party seeking the benefit of the term. Second, the damages must be sufficiently uncertain at the time the contract is made that such a clause will likely save both parties the future difficulty of estimating damages. Damages that are sufficiently uncertain may be referred to as unliquidated damages, and may be so categorized because they are not mathematically calculable or are subject to a contingency which makes the amount of damages uncertain.

For example, suppose Joey agrees to lease a storefront to Monica, from which Monica intends to sell jewelry. If Joey breaches the contract by refusing to lease the storefront at the appointed time, it will be difficult to determine what profits Monica will have lost, because the success of newly created small businesses is highly uncertain. This, therefore, would be an appropriate circumstance for Monica to insist upon a liquidated damages clause in case Joey does indeed fail to perform.

The law applied to bank and credit card charges

This law has recently been of great interest to bank and credit card customers who have been charged as much as $£ 38$ for a single transaction that took them 
over their credit limit. Consumers argued these charges were well beyond the cost of sending a computerised letter.

In 2006 the Office of Fair Trading investigated the excessively high charges being imposed on customers of Credit card companies. In its report, the OFT confirmed these charges were unlawful under UK Law as they amounted to a penalty. It said it would be prepared to investigate any charge over $£ 12$, though this was not intended to indicate that $£ 12$ is a fair and acceptable charge. The OFT said it would be up to a court to determine such an amount based on the established legal precedent that the only recoverable cost would be actual costs incurred.

The credit card companies did not produce evidence of their actual costs to the OFT, instead insisting their charges are in line with clear policy and information provided to customers.

Following the ruling, many bank customers have made County Court claims against their banks and credit card companies for return of penalty charges for returned cheques, direct debits and unauthorised overdraft charges. To date no bank or credit card company, save NatWest on one occasion, has attended at Court for a Trial.

Penal damages

Penal damages are best seen as quantitatively excessive liquidated damages and are invalid under the common law. While liquidated damages are a priori calculations of expectation loss under the contract, penal damages go further and seek to penalise a party in some way for breach of a clause above and beyond the loss suffered by the innocent party as a result of this breach. Many clauses which are found to be penal are expressed as liquidated damages clauses but are seen by courts as excessive and thus invalid.

The judicial approach to penal damages is conceptually important as it is one of the few examples of judicial paternalism in contract law. Even if two parties genuinely and without coercion wish to consent to a contract which includes a penal clause, they are unable to. So, for example, a person wishing to give up smoking cannot contract with a third party to be fined $\$ 100$ each time they smoke as this figure does not represent the expectation loss of the contract.

Rescission 
In contract law, rescission (to rescind or set aside a contract) refers to the cancellation of the contract between the parties. This is done to bring the parties as far as possible to the position they were before they entered into a contract (the "status quo ante"). This equitable remedy and is discretionary. The court may decline to rescind a contract if one party has affirmed the contract by his action (see Long $v$ Lloyd [1958] 1 WLR 753) or a third party has acquired some rights or there has been substantial performance in implementing the contract. In insurance, rescission is the termination of a contract from the beginning (as if it never existed). The insurer has the right to rescind a policy due to concealment, material misrepresentation, or material breach of warranty.

In American government, rescission authority rests with the President. This authority was granted in the Congressional Budget and Impoundment Control Act of 1974. The President can force Congress to vote on rescinding (or permanently withholding) already appropriated funds. The average amount Presidents have requested since 1974 has been approximately \$15 billion.

Quasi-contractual obligations

Estoppel

Estoppel is a doctrine in common law jurisdictions recognised both at law and in equity in various forms. In general it protects a party who would suffer detriment if:

- The defendant has done or said something to induce an expectation

- The plaintiff relied (reasonably) on the expectation...

- $\quad$...and would suffer detriment if that expectation were false.

Unconscionability by the defendant has been recognised as another element by courts, in an attempt to unify the many individual rules of estoppel. In most cases, it is only a defense that prevents a plaintiff from enforcing legal rights, or from relying on a set of facts that would give rise to enforceable rights (e.g. words said or actions performed) if that enforcement or reliance would be unfair to the defendant. Because its effect is to defeat generally enforceable legal rights, the scope of the remedy is often limited.

For an example of estoppel, think about the case of a debtor and a creditor. The creditor might unofficially inform the debtor that the debt has been forgiven. Even if the original contract was not terminated, the creditor may be estopped from collecting the debt if he changes his mind later. It would be unfair to allow 
the creditor to change his mind in light of the unofficial agreement he made with the debtor beforehand. In the same way, a landlord might inform a tenant that rent has been reduced, for example, if there is construction or a lapse in utility services. If the tenant relies on this advice, the landlord could be estopped from collecting rent retroactively.

Estoppel is closely related to the doctrines of waiver, variation, and election and is applied in many areas of law, including insurance, banking, employment, international trade, etc. In English law, the concept of Legitimate expectation in the realm of administrative law and judicial review is estoppel's counterpart in public law, albeit subtle but important differences exist.

This term appears to come from the French estoupail or a variation, which meant "stopper plug", referring to placing a halt on the imbalance of the situation. Ultimately, it comes from the Latin stopare, "to stop".

Overview

Definition

Estoppel in English law is defined as: "a principle of justice and of equity. It comes to this: when a man, by his words or conduct, has led another to believe in a particular state of affairs, he will not be allowed to go back on it when it would be unjust or inequitable for him to do so." in Moorgate Mercantile v Twitchings [1976] 1 QB 225, CA at 241 per Lord Denning MR.

The definition in American law is similar: "Speaking generally, estoppel is a bar which precludes a person from denying or asserting anything to the contrary of that which has, in contemplation of law, been established as the truth, either by the acts of judicial or legislative officers, or by his own deed, acts, or representations, either express or implied." 28 Am Jur 2d Estoppel and Waiver \$1

\section{Major types}

The main species of estoppel under English, Australian, and American laws are:

- Estoppel by record This frequently arises as issue/cause of action estoppel, judicial estoppel or res judicata where the orders or judgments made in previous legal proceedings prevent the parties from relitigating the same issues or causes of action, 
- $\quad$ Estoppel by deed Where rules of evidence (often regarded as technical or formal estoppels) prevent a litigant from denying the truth of what was said or done, and

- Reliance-based estoppels these are the most important forms. Under English law, this class includes estoppel by representation of fact; promissory estoppel and proprietary estoppel (see Halsbury's Laws of England, Vol 16(2), 2003).

o Estoppel by representation of fact is known as equitable estoppel in American law.

O Equitable estoppel as understood in English law includes:

promissory estoppel,

proprietary estoppel,

Although some authorities regard reliance-based estoppels as mere rules of evidence, they are in reality rules of substantive law.

- Laches is estoppel by delay. Laches has been considered both a reliancebased estoppel, and a sui generis type of estoppel.

Reliance-based estoppels

Under English law, estoppel may be:

- by representation of fact, where one person asserts the truth of a set of facts to another;

- $\quad$ promissory estoppel, where one person makes a promise to another, but there is no enforceable contract; and

- $\quad$ Proprietary estoppel, where the parties are litigating the title to land.

These are regarded as reliance-based estoppels by Halsbury's Laws of England, Vol 16(2), 2003. Both Halsbury's and Spencer Bower (see below) describe all three estoppels collectively as estoppels by representation. More simply, one party must say or do something and see the other party rely on what is said or done to change behavior. So, suppose that:

- D has the money to repay a debt,

- but the creditor tells $D$ that the debt is forgiven,

- $\quad$ so, without doing anything else, D buys a car that he would not otherwise have been able to afford,

- And the creditor is aware of this reaction. 
D is a bare promisee/representee. The original contract is still valid because $D$ has not given any value or consideration to make the termination of liability legally binding. Under normal circumstances, a court will not enforce a bare promise but $D$ may be given a remedy if, and only if, the judge decides that it would be "unconscionable" for the creditor to renege on the promise or represention knowing that D would be penalized. Estoppel is, therefore, an exception to the normal operation of the law and gains its power from equity. Only proprietary estoppel can create a cause of action in English law (and, then, only in very limited circumstances), while the other two can support a defence and a counterclaim. Under Australian law, these estoppels can create both a cause of action and a defense. Under American law, equitable estoppel is available only as a defense, while promissory estoppel can be used as the basis of a cause of action.

To establish a reliance-based estoppel, the victimised party must be able to show both inducement and detrimental reliance, i.e.:

- there must be evidence to show that the representor actually intended the victim to act on the represention or promise, or

- the victim must satisfy the court that it was reasonable for him or her to act on the relevant representation or promise, and

- what the victim did must either have been reasonable, or

- the victim did what the representor intended, and

- the victim would suffer a loss or detriment if the representor was allowed to deny what was said or done - detriment is measured at the time when the representor proposes to deny the representation or withdraw the promise, not at the time when either was made, and

- In all the circumstances, the behavior of the representor is such that it would be "unconscionable" to allow him or her to resile.

Estoppel by representation of fact and promissory estoppel are mutually exclusive: the former is based on a representation of existing fact (or of mixed fact and law); while the latter is based on a promise not to enforce some preexisting right (i.e. it expresses an intention as to the future). A proprietary estoppel operates only between parties who, at the time of the representation, were in an existing relationship, while this is not a requirement for estoppel by representation of fact. 
The test for unconscionability in the English and Australian courts takes many factors into account, including the behavior, state of mind and circumstances of the parties. Generally, the following eight factors are determinative (Michael Spence, Protecting Reliance: The Emergent Doctrine of Equitable Estoppel, Oxford: 1999, pp60-66):

- how the promise/representation and reliance upon it were induced;

- the content of the promise/representation;

- the relative knowledge of the parties;

- the parties' relative interest in the relevant activities in reliance;

- the nature and context of the parties' relationship;

- the parties' relative strength of position;

- the history of the parties' relationship; and

- The steps, if any, taken by the promisor/representor to ensure he has not caused preventable harm.

Estoppel by representation of fact

In English law, estoppel by representation of fact is a term coined by Spencer Bower. This species of estoppel is also referred to as "common law estoppel by representation" in Halsbury's Laws of England, vol 16(2), 2003 reissue.

In The Law relating to Estoppel by Representation, 4th edition, 2004 at para I.2.2, Spencer Bower defines estoppel by representation of fact as follows:

Where one person ('the representor') has made a representation of fact to another person ('the representee') in words or by acts or conduct, or (being under a duty to the representee to speak or act) by silence or inaction, with the intention (actual or presumptive) and with the result of inducing the representee on the faith of such representation to alter his position to his detriment, the representor, in any litigation which may afterwards take place between him and the representee, is estopped, as against the representee, from making, or attempting to establish by evidence, any averment substantially at variance with his former representation, if the representee at the proper time, and in proper manner, objects thereto.

A second definition can be found at Wilken and Villiers, The Law of Waiver, Variation and Estoppel, 2nd ed, Oxford: 2003, at para 9.02:

An estoppel by representation [of fact] will arise between $A$ and $B$ if the following elements are made out. First, A makes a false representation of fact to 
B or to a group of which B was a member. [It is not necessary to demonstrate A knew that the representation was untrue.] Second, in making the representation, an intended or [in the alternatively,] knew that it was likely to be acted upon. Third, B, believing the representation, acts to its detriment in reliance on the representation. [It must have been reasonable to rely on the representation.] Fourth, A subsequently seeks to deny the truth of the representation. Fifth, no defence to the estoppel can be raised by $A$.

A representation can be made by words or conduct. Although the representation must be clear and unambiguous, a representation can be inferred from silence where there is a duty to speak or from negligence where a duty of care has arisen. Under English law, estoppel by representation of fact usually acts as a defence, though it may act in support of a cause of action or counterclaim.

Although there is some debate as to whether "unconscionability" is an element that English courts need to take into account when considering estoppel by representation of fact, the Australian courts clearly do (see Wilken and Villiers, para 9-03; The Commonwealth v Verwayen (1990) 170 CLR 394 at 444 per Deane J.)

Equitable estoppel

As noted above, although both English and Australian laws treat promissory and proprietary estoppels as species of equitable estoppel, the status of estoppel by representation of fact is less clear in Australia. The decisions of Waltons Stores (Interstate) v Maher (1988) 164 CLR 387 and Commonwealth v Verwayen (1990) 170 CLR 394, both purport to fuse common law and equitable estoppels into a single unified doctrine, but the New South Wales Court of Appeal in Bryon Shire Council v Vaughan [2002] NSWCA 158 continues to treat estoppel by representation at common law as distinct from equitable estoppel. (See Meagher, Gummow \& Lehane's Equity: Doctrines \& Remedies, 4th edition, Butterworth: 2002, Chapter 17 and Pakinson, the Principles of Equity, 2nd edition, LBC: 2003, Chapter 7). This can be significant in deciding which court has jurisdiction to adjudicate on the issue.

The American doctrine of equitable estoppel is the same as the English estoppel by representation of fact:

The most comprehensive definition of equitable estoppel or estoppel in pais is that it is the principle by which a party who knows or should know the truth is 
absolutely precluded, both at law and in equity, from denying, or asserting the contrary of, any material fact which, by his words or conduct, affirmative or negative, intentionally or through culpable negligence, he has induced another, who was excusably ignorant of the true facts and who had a right to rely upon such words or conduct, to believe and act upon them thereby, as a consequence reasonably to be anticipated, changing his position in such a way that he would suffer injury if such denial or contrary assertion was allowed. 28 Am Jur 2d Estoppel and Waiver $§ 28$

Proprietary estoppel

The traditional version of proprietary estoppel arises in negotiations affecting title to land. So if:

- one party represents that he or she is transferring an interest in land to another, but what is done has no legal effect, or

- merely promises at some time in the future to transfer land or an interest in land to another, and

- knows that the other party will spend money or otherwise act to his or her detriment in reliance on the supposed or promised transfer,

An estoppel may arise. Thus, in Dillwyn v Llwellyn (1862) 4 De G.F. \& J. 517 C.A. a father promised a house to his son who took possession and spent a large sum of money improving the property. The father never actually transferred the house to the son. When his father died, the son claimed to be the equitable owner and the court ordered the testamentary trustees to convey the land to him. See also Inwards v Baker [1965] 2 Q.B. 29, C.A.

In Wilmott v Barber (1880) 15 Ch D 96, Fry J considered that five elements had to be established before proprietary estoppel could operate:

- the plaintiff must have made a mistake as to his legal rights;

- the plaintiff must have done some act of reliance;

- the defendant, the possessor of a legal right, must know of the existence of his own right which is inconsistent with the right claimed by the plaintiff;

- the defendant must know of the plaintiff's mistaken belief; and

- The defendant must have encouraged the plaintiff in his act of reliance.

Although proprietary estoppel was only traditionally available in disputes affecting title to real property, it has now gained limited acceptance in other 
areas of law. Proprietary estoppel is closely related to the doctrine of constructive trust.

The term "proprietary estoppel" is not used in American law, but the principle is part and parcel of the general doctrine of promissory estoppel.

Promissory estoppel

The doctrine of promissory estoppel prevents one party from withdrawing a promise made to a second party if the latter has reasonably relied on that promise and acted upon it.

English law

In English law, a promise made without consideration is generally not enforceable. It is known as a bare or gratuitous promise. Thus, if a car salesman promises not to sell a car over the weekend, but does so, the promise cannot be enforced. But should the car salesman accept even one penny in consideration for the promise, the promise will be binding and enforceable in court. Estoppel is not an exception to this rule.

The doctrine of promissory estoppel was first developed in Hughes $v$. Metropolitan Railway Co [1877] but was lost for some time until it was resurrected by Lord Denning in the controversial case of Central London Property Trust Ltd v. High Trees House Ltd [1947] K.B. 130.

In this case, the plaintiffs leased a block of flats to the defendants at an annual rent of $£ 2500$ - but, because the defendants were unable to find enough tenants while London was being bombed during WWII, they agreed to accept a reduction in rent to $£ 1250$. There was no consideration for this promise to accept a lower rent. At the end of the war the flats were again fully let, and the plaintiffs claimed the full rent for the remainder of the contract beginning the final half of that year, 1945. Denning $J$ held that, in good conscience, they were entitled to the full rent from the end of the war, but noted that they were estopped from going back on their promise had they claimed rents from the wartime period as well. Promissory estoppel requires:

- (I) an unequivocal promise by words or conduct,

- (ii) evidence that there is a change in position of the promisee as a result of the promise (reliance but not necessarily to their detriment),

- $\quad$ (iii) Inequity if the promisor was to go back on the promise. 
Estoppel is "a shield not a sword" - it cannot be used as the basis of an action on its own. It also does not extinguish rights. In High Trees the plaintiff company was able to restore payment of full rent from early 1945, and could have restored the full rent at any time after the initial promise was made provided a suitable period of notice had been given. It is to be noted that in this case, the estoppel was applied to a 'negative promise', that is, one where a party promises not to enforce full rights.

Estoppel is an equitable (as opposed to common law) construct and its application is therefore discretionary. In the case of $D \& C$ Builders $v$. Rees the courts refused to recognise a promise to accept a part payment of $£ 300$ on a debt of $£ 482$ on the basis that it was extracted by duress. In Combe v. Combe Denning elaborated on the equitable nature of estoppel by refusing to allow its use as a "sword" by an ex-wife to extract funds from the destitute husband.

Promissory estoppel is not available when one party promises to accept a lesser sum in full payment of a debt, unless the debtor offers payment at an earlier date than was previously agreed. This is the rule formulated in Pinnel's Case (1602) 5 Co Rep 117a, and affirmed in Foakes v. Beer (1884) 9 App CAS 605.

Australian law

The doctrine of promissory estoppel was adopted into Australian law in Legione v. Hateley (1983) 152 CLR 406; however, the plaintiffs were unsuccessful in that case because the reliance was unreasonable and the promise not unequivocal.

In fact, now Australian law has gone beyond the position espoused in the High Trees case; it has been extended successfully to cases where there is no preexisting legal relationship between the two parties, and promissory estoppel can be wielded as a "sword", not just as a "shield". Mason CJ and Wilson $\mathbf{J}$ in Waltons Stores (Interstate) Ltd v. Maher (1988) 164 CLR 387 held that if estoppel is proven, it gives rise to an equity in favour of the plaintiff, and the court will do the minimum equity that is just in the circumstances. From this case, it is also possible for the promise to come from silence or inaction.

As noted above, in Australian law, there is an element of unconscionability, which is satisfied if one party encourages the other party to create assumptions that lead to reliance. 
Today, the principle of estoppel may give birth to an enforcable obligation even without a consideration under the following conditions: 1. promise 2. Dishonest behavior of the promittant 3. Special relationship between the promittant and the beneficior (eg: duty of information) 4. Irreversible changement of the situation of the beneficior of the promise

American law

In the many jurisdictions of the United States, promissory estoppel is generally an alternative to consideration as a basis for enforcing a promise. It is also sometimes referred to as detrimental reliance.

The American Law Institute in 1932 included the principle of estoppel into $\$ 90$ of the Restatement of Contracts, stating:

A promise which the promisor should reasonably expect to induce action or forbearance of a definite and substantial character on the part of the promisee and which does induce such action or forbearance is binding if injustice can be avoided only by enforcement of the promise. Restatement (Second) removed the requirement that the detriment be "substantial".

The distinction between promissory estoppel and equitable estoppel should be noted:

Equitable estoppel is distinct from promissory estoppel. Promissory estoppel involves a clear and definite promise, while equitable estoppel involves only representations and inducements. The representations at issue in promissory estoppel go to future intent, while equitable estoppel involves statement of past or present fact. It is also said that equitable estoppel lies in tort, while promissory estoppel lies in contract. The major distinction between equitable estoppel and promissory estoppel is that the former is available only as a defense, while promissory estoppel can be used as the basis of a cause of action for damages. 28 Am Jur 2d Estoppel and Waiver $\$ 35$

Suppose that $B$ goes to a store and sees a sign that the price of a radio is $\$ 10$. $B$ tells the shopkeeper that he will get the money and come back later that day to purchase it; there is no discussion of price. The shopkeeper says that when $B$ returns, he will be happy to deal with $B$ as he deals with all his customers but that, if he sells all the radios (he has three), he will not be able to help B. Hearing this, $B$ goes and sells his watch for $\$ 10$ (it was really worth $\$ 15$, but since $B$ wanted the money right away, he chose not to wait for the best price). When $B$ 
returns, the sign says $\$ 11$, and the owner tells $B$ that he has raised the price. In Equity, can you argue that the shopkeeper is estopped by conduct? B relied upon the implied representation that a radio would be sold for $\$ 10$ when he returned with the money; $B$ has sold his watch at a price lower than the market price, and thus he has acted to his detriment. (Note that if $B$ 's watch was worth $\$ 10$, and he received a fair price, there would be no detriment.) But the problem is that the shopkeeper did not guarantee to hold one of the radios against the possibility of B's return nor did they agree a fixed price. The shopkeeper's conscience might have been affected if he had known that $B$ was going home to collect the money and would definitely return to buy one of the three radios. Indeed, in some common law jurisdictions, a promise by the shopkeeper to hold a specific radio would create a binding contract, even if $B$ had to go for the money. A promise to pay the owner in the future is good consideration if it is made in exchange for a promise to sell a specific radio (one from three is probably sufficiently specific): one promise in exchange for a second promise creates equal value. So the shopkeeper's actual words and knowledge are critical to deciding whether either a contract or an estoppel arises.

For an example of promissory estoppel in the construction industry, suppose that B Ltd consolidates estimates from a number of subcontractors and quotes a single price on a competitive tender. The client accepts B Ltd's quote and construction begins. But one of the subcontractors then claims reimbursements above its original estimate and, because of this change, B Ltd cannot profit from the works. If both parties knew that the accuracy of the individual estimates was critical to the success of the tender and the profitability of the contract as a whole, a court might apply promissory estoppel and allow B Ltd to pay only what the subcontractor originally estimated rather than the new, higher price. But, if both parties hoped that there would be an opportunity to increase the contract prices to reflect additional expenditure, the subcontractor's conscience would not be as limited in seeking a higher payment and B Ltd might be penalised for not building an adequate contingency sum into the tendered price. One contentious point during the drafting of the Restatement was how to calculate the amount of damages flowing from a promissory estoppel. During the deliberations, the following example was considered: a young man's uncle promises to give him $\$ 1,000$ to buy a car. The young man buys a car for $\$ 500$, 
but the uncle refuses to pay any money. One view was that the young man should be entitled to $\$ 1,000$ (the amount promised), but many believed that the young man should only be entitled to $\$ 500$ (the amount he actually lost). The language eventually adopted for the Second Restatement reads: "The remedy granted for breach may be limited as justice requires." - A formula which leaves quantification to the discretion of the court.

Other estoppels

Estoppel in pais

Estoppel in pais (literally "by act of notoriety", or "solemn formal act") is the historical root of common law estoppel by representation and equitable estoppel. The terms Estoppel in pais and equitable estoppel are used interchangeably in American law.

\section{Estoppel by convention}

Estoppel by convention in English law (also known as estoppel by agreement) occurs where two parties negotiate or operate a contract but make a mistake. If they share an assumption, belief or understanding of how the contract will be interpreted or what the legal effect will be, they are bound by that belief, assumption or understanding if:

- (I) they both knew the other had the same belief, and

- $\quad$ (ii) They both based their subsequent dealings on those beliefs.

Some say that that estoppel by convention is not truly an estoppel in its own right, but merely an instance of reliance-based estoppel (estoppel by representation would be its most frequent form). Others see it is no more than an application of the rule of interpretation that, where words in a contract are ambiguous, you always interpret those words so as to give effect to the actual intentions of the parties even though that would not be the usual legal outcome.

Estoppel by acquiescence

Estoppel by acquiescence may arise when one person gives a legal warning to another based on some clearly asserted facts or legal principle, and the other does not respond within "a reasonable period of time". By acquiescing, the other person is generally considered to have lost the legal right to assert the contrary. As an example, suppose that Jill has been storing her car on Jack's land with no contract between them. Jack sends a registered letter to Jill's legal address, stating: "I am no longer willing to allow your car to stay here for free. Please 
come get your car, or make arrangements to pay me rent for storing it. If you do not do so, within 30 days, I will consider the car abandoned and will claim ownership of it. If you need more time to make arrangements, please contact me within 30 days, and we can work something out." If Jill does not respond, she may be said to have relinquished her ownership of the car, and estoppel by acquiescence may prevent any court from invalidating Jack's actions of registering the car in his name and using it as his own.

Estoppel by deed

Estoppel by deed is a rule of evidence arising from the status of a contract signed under seal - such agreements, called deeds, are more strictly enforced than ordinary contracts and the parties are expected to take greater care to verify the contents before signing them. Hence, once signed, all statements of fact (usually found in the opening recital which sets out the reason(s) for making the deed) are conclusive evidence against the parties who are estopped from asserting otherwise.

Issue Estoppel

Issue Estoppel or Res Judicata The civil law use of issue estoppel or res judicata (literally translated as "the fact has been decided") is relatively uncontroversial. It expresses a general public interest that the same issue should not be litigated more than once even when the parties are different. The criminal law application, called double jeopardy provides that a person should not be tried twice for the same offence. In crime/mystery fiction, it is a common plot device to have the villain exploits the rule. In the world of real crime, some cases have achieved notoriety, e.g. in the Birmingham Six saga, the House of Lords ruled in Hunter v. Chief Constable of the West Midlands Police (1982) that issue estoppel applied. Lord Diplock said:

The inherent power which any court of justice must possess to prevent misuse of its procedure in a way which, although not inconsistent with the literal application of its procedural rules, would nevertheless be manifestly unfair to a party to litigation before it, or would otherwise bring the administration of justice into disrepute among right-thinking people.

Quantum meruit 
Quantum meruit is a Latin phrase meaning "as much as he has deserved". In the context of contract law, it means something along the lines of "reasonable value of services".

\section{Situations}

The concept of quantum meruit applies to the following situations:

I. When a person employs (impliedly or expressly) another to do work for him, without any agreement as to his compensation, the law implies a promise from the employer to the workman that he will pay him for his services, as much as he may deserve or merit.

II. When there is an express contract for a stipulated amount and mode of compensation for services, the plaintiff cannot abandon the contract and resort to an action for a quantum meruit on an implied assumpsit.

\section{Examples}

I. The famous example used in United States law schools is usually as follows:

A Man (plaintiff in this hypothetical) talks to a neighbor (defendant) and tells him he's going to build a wall on their property that will give a benefit to both the man and his neighbor. The neighbor neither agrees nor disagrees with what the man wants to build. The man builds the wall, and then asks the neighbor to compensate him for the benefit of the wall that he conferred on the neighbor (usually half the value of the wall). The neighbor refuses. The man is entitled to some compensation based on quantum meruit. This is because there was an implied promise between the man and the neighbor, which is derived from contract law, because the man was acting under the assumption that the neighbor would pay for part of his services. The plaintiff files suit in court on the basis of quantum meruit. The plaintiff makes an estimation of value conferred on the defendant, which the defendant has not paid. Plaintiff will likely win because of quantum meruit. The winning of the case will be directed as an assumpsit on a quantum meruit.

II. This is not the only factual scenario where this will work. Quantum meruit will also work where there is a breached contract.

A contractor is contracted to work on a school. The contractor does some work but messes up part of the work (breach of contract). The school suspends the construction work because of the problem. The contractor is entitled to be paid 
for the services he has already done for the school on the basis of quantum meruit.

III. If a plaintiff is prohibited from completing work based on a long term service contract where other contacts have been negotiated, the plaintiff may ask a court to determine a judgment based on the amounts that the defendant benefited. Third parties may also bring actions against the plaintiff.

A Promoter enters into a long term service contract with a Theatre to exclusively present events for a specified period. The promoter books events and contracts with others to perform during the entire period but alleges that the theatre is unsafe. The Promoter withholds payments until the theatre is made safe. The Theatre performs no repairs. Instead the Theatre terminates the entire service contract before the benefit of the events occurs to the plaintiff and refuses to repair the theatre. After the contract is terminated, the theatre operates the events negotiated by the promoter and gains a significant benefit but does not pay the promoter anything. The theatre also cancels some events without cause. A court determines that the promoter is entitled to an assumpsit on a quantum meruit.

\section{References}

1. $\wedge$ Hans Wehberg, Pacta Sunt Servanda, The American Journal of International Law, Vol. 53, No. 4 (Oct., 1959), p.775; access here at JSTOR

2. $\wedge$ e.g. In England, s. 52, Law of Property Act 1900

3. ^ Carlill v. Carbolic Smoke Ball Company [1893] 2 QB 256

4. ^ e.g. Lord Steyn, Contract Law: Fulfilling the Reasonable Expectations of Honest Men (1997) 113 LQR 433; c.f. § 133 BGB in Germany, where "the actual will of the contracting party, not the literal sense of words, is to be determined"

5. $\wedge$ Restatement (Second) of Contracts $\$ 32$ (1981) (emphasis added)

6. $\wedge$ e.g. In Germany, § 313 BGB

7. ^ Chappell \& Co Ltd v Nestle Co Ltd [1959] 2 All ER 701.

8. $\quad \wedge$ Eastwood v. Kenyon (1840) 11 Ad\&E 438 
9. ^ Austotel v. Franklins (1989) 16 NSWLR 582

10. ^ e.g. P.S. Atiyah, 'Consideration: A Restatement' in Essays on Contract (1986) p.195, Oxford University Press

11. ^ Central London Property Trust Ltd. v. High Trees House Ltd. [1947] KB 130

12. ^ Balfour v. Balfour [1919] 2 KB 571

13. ^ Merritt v. Merritt [1970] 2 All ER 760; [1970] 1 WLR 1211; CA

14. $\wedge \S 105$, II BGB

15. ^ L'Estrange v. F Graucob Ltd [1934] 2 KB 394

16. ^ Curtis v. Chemical Cleaning and Dyeing Co [1951] 1 KB 805

17. ^ Balmain New Ferry Company Ltd v. Robertson (1906) 4 CLR 379

18. ^ Hillas v. Arcos Ltd (1932) 147 LT 503

19. ^ Whitlock v. Brew (1968) 118 CLR 445

20. ^ Three Rivers Trading Co., Ltd. v. Gwinear \& District Farmers, Ltd. (1967) 111 Sol. J. 831

21. ^ Oscar Chess Ltd v. Williams [1957] 1 WLR 370

22. ^ Codelfa Construction Pty Ltd v. State Rail Authority of New South Wales (1982) 149 CLR 337

23. ^ Byrne and Frew v. Australian Airlines Ltd (1995) 185 CLR 410

24. ^ Liverpool City Council v. Irwin [1976] 2 WLR 562)

25. ^ Con-stan Industries of Australia Pty Ltd v. Norwich Winterthur Insurance (Australia) Ltd (1986) 160 CLR 226

26. ^ Frigaliment Importing Co., Ltd., v. B.N.S. International Sales Corp., 190 F. Supp. 116 (S.D.N.Y. 1960) (plaintiff failed to prove what he meant by "chicken") and U.C.C. $§ 1-205$.

27. ^ Coal Cliff Collieries Pty Ltd v. Sijehama Pty Ltd (1991) 24 NSWLR 1

28. $\wedge$ Masters v. Cameron (1954) 91 CLR 353

29. ^ Meehan v. Jones (1982) 149 CLR 571

30. ^ Gordon v. Selico (1986) 18 HLR 219

31. ^ Bisset v Wilkinson and others [1927] AC 177

32. ^ Esso Petroleum Co Ltd v Mardon [1976] 2 Lloyd's Rep. 305

33. ^ Smith v. Hughes [1871]

34. ^ ^ Lewis v Avery [1971] 3 All ER 907

35. ^ Raffles v. Wichelhaus (1864) 2 Hurl. \& C. 906. 
36. ^ Bell v Lever Brothers Ltd. [1931] ALL E.R. Rep. 1, [1932] A.C. 161

37. ^ Black's Law Dictionary (8th ed. 2004)

38. ^ Barton v. Armstrong [1976] AC 104

39. ^ Johnson v. Buttress (1936) 56 CLR 113

40. ^ see in the U.K. e.g. s.3(2) Sale of Goods Act 1979

41. ^ Royal Bank of Canada v. Newell 147 D.L.R (4th) 268 (N.C.S.A.)

42. ^ Beatson (1998)" Anson's Law of Contract", 27th ed. (Oxford: OUP), p.246

43. ^ Beatson, Anson's Law of Contract (1998) 27th ed. OUP, p.21

44. Ewan McKendrick, Contract Law - Text, Cases and Materials (2005) Oxford University Press ISBN 0-19-927480-0

45. P.S. Atiyah, The Rise and Fall of Freedom of Contract (1979) Clarendon Press ISBN 0198253427

46. Randy E. Barnett, Contracts (2003) Aspen Publishers ISBN 0-7355-65352 